\title{
THE POLITICAL PARTIES AND CAMPAIGN FINANCE REFORM
}

\author{
Richard Briffault*
}

\begin{abstract}
Recent campaign finance innovations of the major political parties have blown large and widening holes in federal campaign finance regulation. The relationship between parties and candidates also challenges the basic doctrinal categories of campaign finance law. The Constitution permits regulation of campaign finances to deal with the danger of corruption. But some judges and commentators have argued that the parties present no danger of corruption. This Article finds that, although parties play a positive role in funding campaigns, certain party practices raise the specter of corruption in the constitutional sense. Moreover, due to the close connection between parties and candidates, and the parties' role in linking private donors to key participants in the legislative process, party campaign practices may, constitutionally, be subject to greater regulation than comparable practices of nonparty political organizations. The Article presents specific proposals for dealing with the party activities that have undermined campaign finance law, and argues that such reforms would also bolster the positive role the parties play in the political process.
\end{abstract}

\section{INTRODUCTION}

The major political parties present a central, and particularly nettlesome, difficulty for federal campaign finance regulation. In the last decade, party campaign finance practices have blown large, and widening, holes in the campaign finance system that Congress created with the Federal Election Campaign Act ("FECA"), ${ }^{1}$ and that the Supreme Court modified and sustained in Buckley $v$. Valeo. ${ }^{2}$ Through the development of soft money, ${ }^{3}$ the parties have enabled donors to avoid FECA's contribution caps, its ban on the use of corporate and union treasury funds in federal elections, and its limitation on spending by presidential candidates who choose to accept public funding. By exploiting so-called "issue advocacy" advertising, ${ }^{4}$ the parties have successfully channeled millions of dollars otherwise prohibited by FECA into the heart of federal election campaigns. The Supreme Court's 1996 determination that parties may

* Vice-Dean and Joseph P. Chamberlain Professor of Legislation, Columbia University School of Law.

1. Federal Election Campaign Act of 1971, 2 U.S.C. $\S \S 431-455$ (1994 \& Supp. IV 1998) (amended 1974). The laws providing for the public funding of presidential candidates are technically distinct from FECA. See Presidential Campaign Fund Act, 26 U.S.C. \$\$ 9001-9012 (1994), Presidential Primary Matching Payment Account Act, 26 U.S.C. \$§ 9031-9042 (1994). I will, however, be referring to FECA as a shorthand for the federal campaign finance laws generally, including the presidential public funding laws.

2. 424 U.S. 1 (1976).

3. Soft money is explained more fully in the text accompanying infra notes $33-45$.

4. The concept of issue advocacy is explained in text accompanying infra notes $436-559$. 
engage in independent spending in support of party candidates ${ }^{5}$ has provided the parties with yet another opening to evade the basic structure of FECA, although the greater opportunities offered by the combination of soft money and issue advocacy have, for the moment at least, muted the role of party independent spending.

These party finance techniques are not simply instances of clever adaptation to the FECA-Buckley regime, although the gaming of the system by donors and politicians and the failure of Congress over the last quarter century to respond to campaign finance innovations are part of the story. Rather, these party practices grow out of fault lines central to the constitutional law of campaign finance. As a result, closing the loopholes exploited by the parties presents difficult constitutional questions. Nevertheless, as I will indicate in this Article, new rules that would curb the party activities that are eroding the campaign finance laws can be adopted consistent with the principles enunciated in Buckley. Indeed, such laws are essential to address a fundamental concern of the FECABuckley regime-the prevention of the undue influence of private wealth, and the appearance of such influence, on government decisionmaking.

This Article considers the place of the major political parties in our campaign finance system - the role the parties currently play, the constitutional doctrines that must be considered in regulating the parties, the reasons for regulating party activities currently beyond the scope of FECA, and some legislative proposals for bringing party campaign finance practices into closer compliance with the values that inform our campaign finance laws. ${ }^{6}$

Part I takes stock of the FECA regime as it has evolved in the last two decades. In particular, it analyzes how FECA affects the parties, and how, in turn, the major party campaign finance innovations have emerged outside of FECA to the point that they are now eroding the efficacy of federal campaign finance law.

5. See Colorado Republican Fed. Campaign Comm. v. FEC, 518 U.S. 604-13 (1996) (plurality opinion).

6. This Article focuses solely on the campaign finance practices of the major political parties and on the constitutional issues posed by efforts to regulate the activities of these parties. Two major parties, the Democratic and Republican parties, have held the Presidency and the overwhelming majority of seats of both houses of Congress throughout the twentieth century. As a result, these parties-and any other parties that become "major" in the future-are and ought to be the central focus of the application of campaign finance law to the parties. Cf. 26 U.S.C. $§ 9002$ (6), (7), (8) (distinguishing, based on percentage of the popular vote received in the last presidential election, among "major," "minor," and "new" parties, for purposes of the presidential public funding system). Minor parties may pose policy and constitutional issues different than those affecting the major parties, cf. Brown v. Socialist Workers ' 74 Campaign Comm., 459 U.S. 87 (1982) (holding unconstitutional the application of FECA's disclosure requirements to a minor party that had been the subject of government harassment), and are beyond the scope of this article. Even when the text does not refer to "major" parties specifically, the major parties are its intended focus. 
Part II considers the constitutional questions that would be raised by efforts to regulate these party campaign finance practices. The constitutional law of campaign finance is framed by Buckley $v$ Valeo, but the major political parties present special problems for the application of the Buckley doctrine. First, Buckley assumes a sharp separation between candidates, on the one hand, and politically active organizations, such as political action committees ("PACs") that participate in the electoral process, on the other. Buckley permits greater regulation of such organizations when an organization works with a candidate-such as by giving the candidate a contribution or coordinating its spending with a candidate-than when the organization operates independently. The major parties, however, nominate candidates, are composed of candidates, and are primarily focused on the election of candidates. The close structural connection between the major parties and their candidates blurs the line that Buckley posits between candidates and political organizations and complicates Buckley's efforts to distinguish between activity coordinated with and that independent of a candidate.

Similarly, Buckley differentiates between an organization's financial support for activity involving the discussion of political issues and its financial support of efforts to elect candidates, and permits regulation of only candidate-election-related activities. Again, this assumes that organizations that participate in politics have goals other than the election of candidates. But the overarching concern of the major parties is with winning elections. As a result, the Court's distinction between "issue advocacy" and the "express advocacy" of the election of candidates is particularly problematic when applied to party spending.

Finally, Buckley provides that the only basis for limiting campaign finance activities is to prevent "corruption"-broadly defined to include improper influence and opportunities for abuse, as well as quid pro quo arrangements - and the appearance of corruption. ${ }^{7}$ But many political scientists and several members of the Supreme Court have argued that party campaign finance activities raise little danger of corruption. In their view, the very closeness of the party-candidate relationship, which undermines the applicability of the PAC model and PAC-based views of independent spending and issue advocacy in the party context, also eliminates the issue of corruption. If parties and candidates are so intertwined and have such common interests that the former cannot corrupt the latter, then all present and proposed rules limiting party money rest on shaky constitutional foundation.

I argue that the close relationship between parties and candidates renders the PAC model of the candidate-organization relationship and of political organization's electoral speech inapposite to parties. The doctrinal distinctions Buckley draws can and should be interpreted differently in

7. 424 U.S. 1, at 28. See also Nixon v. Shrink Mo. Gov't PAC, 120 S.Ct. 897, 905 (2000). 
the party context, in light of the party-candidate relationship, so as to define more party activities as coordinated with candidates and to treat more party expenditures as election-related. I will also argue that the closeness of the party-candidate relationship does not eliminate the question of corruption. Rather, once the connections linking parties, donors to parties, and candidates are examined, it is clear that unlimited donations to and spending by the parties raise issues of "corruption" within Buckley's meaning.

Part III presents and defends proposals for dealing with the three principal party threats to the campaign finance system that have emerged in the last decade: party independent expenditures, soft money, and party issue advocacy. ${ }^{8}$ These proposals would narrow the definitions of independent expenditures and issue advocacy in the party context, while subjecting all donations to party activities concerning federal elections to FECA's restrictions. By so doing, they seek to harmonize the rights of parties to engage in constitutionally protected political activity, and the benefits of party participation in federal elections, with the goal of restoring the integrity of the campaign finance system. These proposals should not be seen as anti-party. The parties play a positive role in our political system. Indeed, I will suggest that once party money is brought back under FECA, increasing the amount of money the parties are allowed to spend in support of their candidates would actually be desirable. But unlimited contributions to, and unlimited spending by, the parties jeopardizes the anti-corruption values at the heart of campaign finance law. Unless party money is subject to effective limits, campaign finance reform is doomed to failure.

8. As this Article was going to press, a fourth and potentially very significant new party threat to the campaign finance system emerged. On May 5, 2000, the United States Court of Appeals for the Tenth Circuit invalidated FECA's limits on party expenditures that are coordinated with a party's congressional candidate. See Colorado Republican Fed. Campaign Comm. v. FEC ("Colorado Republican II"), No. 99-1211, 2000 WL 554688 (10th Cir. May 5, 2000). If it stands, Colorado Republican II would render irrelevant the distinction between party-coordinated expenditures and independent expenditures drawn by the Supreme Court in Colorado Republican Fed. Campaign Comm. v. FEC, 518 U.S. 604 (1996). Parties would be able to spend unlimited amounts of hard money in support of their candidates or against candidates of the opposing party. However, the distinctions between hard and soft money, and between party express advocacy and party issue advocacy, would remain significant. A full evaluation of Colorado Republican II is beyond the scope of this Article, but a brief critical assessment of the decision and its implications for reform of the rules governing party campaign finance practices is provided at infra notes 174-190 and accompanying text. 


\section{Party Money Under, And Outside of, FECA}

\section{A. FECA and the Parties ${ }^{9}$}

FECA limits donations to parties by individuals and political action committees ("PACs"). It provides that a person ${ }^{10}$ may contribute up to $\$ 20,000$ per calendar year to the national committees of a political party, and up to $\$ 5000$ per calendar year to a state party committee for activities in connection with federal elections. ${ }^{11}$ A PAC can contribute up to $\$ 15,000$ per calendar year to the national committees of a party, and up to $\$ 5000$ per calendar year to a state party committee for federal election activity. ${ }^{12}$ Corporations and labor unions are prohibited from making any contributions to party activities in support of federal candidates, but they may sponsor PACs that can give to party committees, subject to the dollar limits applicable to PAC contributions. ${ }^{13}$ In this way, FECA's limits on donations to parties generally track the Act's limits on donations to PACs, except that the limits on donations to parties are higher than the limits on donations to other political committees. ${ }^{14}$

9. In the text, I discuss FECA's limits on contributions to parties, and on party support of candidates. The Act also imposes reporting and disclosure requirements on the parties, see 2 U.S.C. $\$ 434$ (a) (4), (b) (1994), and makes the parties whose presidential candidates qualify for public funding eligible for funds to defray the costs of their presidential nominating conventions, see 26 U.S.C. $\$ 9008$ (1994). Some commentators have found that the reporting requirements have had a real impact on party participation in federal elections. They have suggested that FECA's rules contributed to the centralization of party activity from the local to the state level and, at least until the parties became more familiar with FECA, tended to discourage state party involvement in federal races. See, e.g., Paul S. Herrnson, Party Campaigning in the 1980s 28-29 (1988) [hereinafter Herrnson, Party Campaigning in the 1980s]; Xandra Kayden, The Nationalizing of the Party System in Parties, Interest Groups, and Campaign Finance Laws 257, 262-65 (Michael J. Malbin ed., 1980).

10. Under FECA, "person" includes "an individual, partnership, committee, association, corporation, labor organization, or any other organization or group of persons" other than the federal government. 2 U.S.C. $\$ 431$ (11) (1994). FECA imposes additional restrictions on national banks, corporations, and unions. See id. $\$ 441 \mathrm{~b}$.

11. See id. $\S 441 \mathrm{a}(\mathrm{a})(1)(\mathrm{B})$, (C). The limit on contributions to a state party committee also includes contributions to any local party committee within that state.

12. See id. $\S 441 \mathrm{a}(\mathrm{a})(2)$ (B), (C). A PAC may not contribute more than $\$ 5000$ per election to a federal candidate, nor more than $\$ 5000$ per calendar year to another PAC. See id. $\S 441 \mathrm{a}(\mathrm{a})(2)(\mathrm{A}),(\mathrm{C})$. There is no annual limit on aggregate PAC contributions to candidates, party committees, and other PACs.

13. See id. $\S 441 b(a)$. FECA does not specifically prohibit corporation and union contributions to parties: Rather, the Act generally bans corporate and union contributions and expenditures in connection with federal election activities. Contributions to parties fall within the general prohibition on corporate and union financial participation in federal election campaigns.

14. The Act imposes much lower limits on individual contributions to candidates and PACs. A person can contribute no more than $\$ 1000$ per election to a federal candidate, and no more than $\$ 5000$ per calendar year to a PAC. See id. $\S 441 \mathrm{a}(\mathrm{a})(1)(\mathrm{A})$, (C). Total election-related contributions by an individual to candidates, PACs, and party committees may not exceed $\$ 25,000$ in any calendar year. See id. $\S 441 \mathrm{a}(\mathrm{a})(3)$. 
The same provision of FECA that limits PAC contributions also limits party contributions to candidates, although once again FECA treats parties more generously than it treats PACs. Thus, like PACs, party committees-including the national committee, the Senate campaign committee, the House campaign committee, and the state party committeemay each donate up to $\$ 5000$ to a federal candidate per election. ${ }^{15}$

FECA, however, offers the parties two special campaign finance opportunities that are unavailable to PACs. First, the parties may engage in "coordinated expenditures." In general, FECA treats all money spent by an individual or organization in coordination with a candidate as though it were a direct contribution to that candidate, subject to the Act's contribution ceiling. ${ }^{16}$ However, FECA authorizes party committees-and only party committees-to engage in coordinated expenditures with candidates that do not count against the contribution caps. ${ }^{17}$ These party-coordinated expenditures are subject to dollar limits, ${ }^{18}$ but the limits are much higher than the Act's limits on contributions and, unlike the caps on contributions, they are adjusted for inflation. ${ }^{19}$ In addition, a state

15. See id. FECA has a special rule that permits a party national committee, its Senate campaign committee, or the two together to contribute $\$ 17,500$ to a Senate candidate per campaign, e.g., primary and general election together. See id. $\S 441 \mathrm{a}(\mathrm{h})$. FECA generally treats primary, runoff, and general elections as different elections. See id. §431(1)(A). Thus, in a typical election cycle in which a candidate contests both a primary and a general election, the limit on PAC and party committee donations to a candidate is $\$ 10,000$. Similarly, the $\$ 1000$ cap on individual donations to a candidate is $\$ 2000$ per election cycle. As a rule, parties do not contribute to candidates in contested primaries. See Paul S. Herrnson, National Party Organizations at the Century's End, in The Parties Respond: Changes in American Parties and Campaigns 50, 65 (L. Sandy Maisel ed., 3d ed. 1998) [hereinafter Herrnson, National Party Organizations].

16. See 2 U.S.C. $\S 441 \mathrm{a}(\mathrm{a})(7)$ (B) (i).

17. See id. $\S 441 \mathrm{a}(\mathrm{d})$.

18. As this article was going to press, a divided panel of the U.S. Court of Appeals for the Tenth Circuit invalidated FECA's caps on party-coordinated expenditures. See supra note 8 and infra notes $174-190$ and accompanying text.

19. The limits for Senate and presidential races are also based on voting age population ("VAP"). A party national committee may spend two cents per VAP, inflationadjusted from a 1974 base, in support of the party's presidential ticket. See id. $\S 441 \mathrm{a}(\mathrm{d})(2)$. Under this formula, each of the two major national parties will be able to spend $\$ 13.3$ million in coordinated spending in support of its presidential ticket in 2000 . See FEC, Press Release, If the Presidential Election Were Held in 1999 (July 7, 1999) <http://www.fec.gov/press/spend99.htm> (on file with the Columbia Law Review). The national and state parties may also each spend the greater of $\$ 20,000$ in 1974 dollars, or two cents in 1974 prices times state VAP in coordinated expenditures in connection with party Senate candidates, or House of Representatives candidates in a state which has only one House seat. See 2 U.S.C. $\$ 441 \mathrm{a}$ (d) (3) (A). The coordinated spending limit for party spending in support of other House candidates is $\$ 10,000$, inflation-adjusted from a 1974 base. See id. $\$ 441 \mathrm{a}$ (d) (3)(B). In 1998, limits on party-coordinated spending for Senate candidates ranged from $\$ 130,200$ in Alaska to $\$ 3,035,874$ in California. The limit in House races was $\$ 32,550$ in most states, and $\$ 65,100$ in states with only one congressional district. See FEC, Press Release, FEC Announces 1998 Party Spending Limits: Amounts Range from $\$ 130,200$ to $\$ 3$ Million (March 6, 1998) <http://www.fec.gov/press/44lad.htm> (on file with the Columbia Law Review). 
party committee may designate a national party committee-such as the Senate campaign committee for Senate elections or the House campaign committee for elections to the House of Representatives-as its "agent" for coordinated spending. ${ }^{20}$ As the national committees are generally more successful at fundraising than their state counterparts, such agency agreements make it easier for the parties to engage in the maximum coordinated spending permitted by law, and they effectively double the national committee's coordinated expenditure ceiling. Coordinated expenditures are a far more important form of party campaign activity than direct contributions to candidates. Whereas national Republican and Democratic contributions to congressional candidates totaled $\$ 14.7$ million over the last three election cycles, aggregate coordinated expenditures by the parties came to $\$ 129.4$ million. ${ }^{21}$

The second special provision allows state party committees to undertake, without limitation, certain "grass-roots" spending in support of federal candidates. These expenditures include payments for campaign materials used in connection with volunteer activities on behalf of party nominees, and for voter registration and get-out-the-vote drives. ${ }^{22}$ Grassroots spending must be funded by contributions that comply with FECA's dollar caps and source prohibitions, ${ }^{23}$ but there is no ceiling on the amount state parties can spend on these activities. Although nominally a spending opportunity for state parties, the grass-roots exemptions strongly benefit the national parties, which typically raise the funds for grass-roots spending and then transfer them to state and local parties, with directions concerning how they are to be used to aid federal candidates.

The parties, particularly the national party committees, have done well under FECA. They raise far more money than ever before, and they are playing a growing role in the financing of federal election campaigns. The Act's limits on donations to candidates, coupled with the sharp rise in campaign costs, place a premium on intermediary organizations like

20. See, e.g., Frank J. Sorauf, Inside Campaign Finance: Myths and Realities 112-20 (1992). The Supreme Court upheld the transfer of such spending authority in FEC v. Democratic Senatorial Campaign Comm., 454 U.S. 27, 31 (1981).

21. See FEC, Press Release, FEC Reports on Political Party Activity for 1997-98 (April 9, 1999) <http://www.fec.gov/press/ptyye98.htm> (on file with the Columbia Law Review) [hereinafter FEC, Political Party Activity].

These figures may understate the value of coordinated expenditures. Most coordinated expenditures consist of in-kind services: the provision of polling data, mailing lists, assistance with fundraising, campaign management, opposition research, and preparation and placement of advertising. These services are often obtained from consultants who provide them to the parties, as repeat participants in the political process, at a discount, so that their value to the candidate is likely to exceed the cost to the party. See Anthony Gierzynski, Legislative Party Campaign Committees in the American States 53-54 (1992); Herrnson, National Party Organizations, supra note 15, at 73 (stating that party in-kind campaign services "are worth many times more than their reported value").

22. See 2 U.S.C. $\S 431$ (8) (B) (x), (xii), $\$ 431$ (9) (B) (viii), (ix).

23. See 2 U.S.C. $\S 431(8)$ (B) (x) (2), (xii) (2), $§ 431$ (9) (B) (viii) (2), (ix) (2). 
PACs and party committees that can help candidates obtain funds and defray some of their campaign expenses. Although initially PACs were the preeminent beneficiaries of FECA, the national parties emerged over the course of the 1980s as important financial participants in federal elections. For the first time, the national party committees built up a mass financial base, accumulating large aggregates of money through relatively small donations from a large number of donors. ${ }^{24}$ Due to their fundraising prowess, the party congressional campaign committees ("CCCs")which are composed of members of Congress organized by party and chamber-have become significant players in congressional races. They provide candidates with money, aid them in raising funds from PACs and individual donors, and are involved in candidate recruitment, campaign management, the production and placement of candidate ads, and the mobilization of voters. ${ }^{25}$

\section{B. The Growing Role of Party Money Outside of FECA}

In recent years, three new mechanisms have further expanded and reshaped the party campaign finance role: party independent expenditures, soft money, and party issue advocacy. Unlike contributions and coordinated expenditures, however, these devices developed outside of FECA and they now directly challenge the Act's structure of contribution and spending restrictions.

1. Party Independent Expenditures. - Buckley $v$. Valeo invalidated the FECA provision that would have capped the amount of money an individual or group could spend independently of a candidate in support of that candidate or against her opponent. As a result, individuals and PACs may spend unlimited amounts of money on so-called "independent expenditures." ${ }^{26}$ In the first two decades following Buckley it was widely assumed that party electoral spending was necessarily coordinated with candidates, and, thus, that parties could not take advantage of the Supreme Court's protection of independent expenditures. ${ }^{27}$ In 1996, however, a Supreme

24. See, e.g., Herrnson, National Party Organizations, supra note 15, at 59 (stating that the national party organizations raise most of their hard money in the form of direct mail contributions under \$100); Leon Epstein, Political Parties in the American Mold 276-78 (1986) (contrasting historic dependence of the parties on a small number of very large donors with the post-FECA development of a mass financial base).

25. The rising financial and campaign role of the CCCs under FECA is examined in Herrnson, Party Campaigning in the 1980s, supra note 9, at 30-83 (1988) and Robin Kolodny: Pursuing Majorities: Congressional Campaign Committees in American Politics 124-55 (1998).

26. 424 U.S. 1, 39-59 (1976).

27. See David Adamany, Political Parties in the 1980s, in Money and Politics in the United States: Financing Elections in the 1980s 70, 72-73 (Michael J. Malbin ed., 1984); F. Christopher Arterton, Political Money and Party Strength, in The Future of American Political Parties: The Challenge of Governance 101, 116 (Joel L. Fleishman ed., 1982); Kirk J. Nahra, Political Parties and the Campaign Finance Laws: Dilemmas, Concerns and Opportunities, 56 Fordham L. Rev. 53, 97 (1987); see also FEC v. Democratic Senatorial Campaign Comm., 454 U.S. 27, 28 n.1 (1981) ("Party committees are considered incapable 
Court plurality determined in Colorado Republican Federal Campaign Committee v. Federal Election Commission that a party may engage in independent spending, and that such party spending is entitled to the same constitutional protection from limitation that extends to independent spending by PACs or individuals. ${ }^{28}$

Colorado Republican provided the parties with a major opportunity to avoid FECA's limits on party spending in congressional races. In the months immediately following the decision, the national Republican Party put together a $\$ 10$ million independent expenditure program, primarily supporting the party's Senate candidates. ${ }^{29}$ The Democrats lagged with a more modest $\$ 1.5$ million program. ${ }^{30}$ In 1998 , however, the role of party independent spending declined. The Democrats again committed $\$ 1.5$ million (or about $7 \%$ of their combined total of contributions to and spending in support of candidates) to independent expenditures, but Republican party spending dropped to under $\$ 300,000 .^{31}$ The parties' apparent disinterest in exploiting the opportunities for independent spending appears to have resulted from the emergence of another, more attractive means of providing unlimited support for party candidates: the use of party soft money to finance so-called "issue advocacy." 32

2. Soft Money. - Party contributions to candidates, party-coordinated expenditures with candidates, party grass-roots expenditures, and even the party independent expenditures unleashed in Colorado Republican all involve so-called "hard money," that is, money raised in compliance with FECA's dollar limits and source prohibitions. Funding for these activities must abide by FECA's restrictions because those activities involve express support of the election or defeat of federal candidates and, thus, fall within the Act's definitions of "contributions" and "expenditures." But, increasingly, party participation in federal elections is financed by so-called "soft money," that is, money whose collection and disbursement does not comply with FECA. This category includes individual or PAC donations in excess of the Act's dollar limits, and corporate or union donations forbidden by FECA. "Soft money" funds activities that affect federal elections but, due to statutory definition, administrative action, or judicial decision, technically fall outside FECA's scope.

Soft money emerged out of the complications of political federalism. FECA regulates only federal elections, but federal and state elections typically occur concurrently, with candidates for federal and state offices ap-

of making 'independent' expenditures in connection with the campaigns of their party's candidates.").

28. 518 U.S. 604,618 (1996).

29. This compares with $\$ 34.7$ million in contributions to and coordinated expenditures with candidates in 1996. See FEC, Political Party Activity, supra note 21.

30. See id.

31. See id.

32. See Paul S. Herrnson \& Diana Dwyre, Party Issue Advocacy in Congressional Election Campaigns, in The State of the Parties: The Changing Role of Contemporary American Parties 86, 90 (John C. Green \& Daniel M. Shea eds., 3d ed. 1999). 
pearing on one state ballot. Party committees can and do undertake campaign efforts that simultaneously assist both their federal and state candidates. Spending on federal candidates must satisfy FECA, but aid to state candidates is subject only to state law. Many state campaign finance laws are less restrictive than FECA: Some permit corporations or unions to support candidates and some do not limit individual or PAC donations. ${ }^{33}$

In the late $1970 \mathrm{~s}$, various state party committees began to press the FEC to allow them to use funds that did not comply with FECA to partially finance campaign efforts that help the party ticket as a whole, including both federal and state candidates. In 1978 the FEC determined that a state party could use funds impermissible under FECA to defray the non-federal portion of administrative overhead and of the costs of some activities, such as voter registration and voter mobilization, that directly benefit both federal and state candidates. ${ }^{34}$ In 1979, the FEC decided that national party committees could also set up accounts for the deposit and disbursement of funds otherwise barred by FECA to finance support for the non-federal portion of the combined federal-state ticket. ${ }^{35} \mathrm{Soft}$ money was born.

Soft money grew during the 1980 s, rising from $\$ 19$ million in 1980 to $\$ 45$ million in $1988 .{ }^{36}$ It was used to build the infrastructure of the national parties, to hire staff, acquire office space, develop direct mail capability, run polling and issues research operations, acquire data processing equipment, and create and improve facilities for mass media communications-all on the theory that since some portion of these activities is aimed at state and local elections, a portion of the cost could be defrayed by non-federal money. The national parties also transferred millions of dollars in soft money to state parties to build their infrastructures, and especially to fund shared voter mobilization programs such as direct mail campaigns and phone bank operations intended to bring voters to the polls.

In 1990, the FEC responded to years of prodding by campaign finance reformers and the courts, and issued rules, which became effective

33. In 1996, fifteen states placed no limits on individual contributions and eighteen states placed no limits on PAC contributions. Some states with contribution ceilings use higher limits than FECA. Eight states had no limits on corporate contributions and twelve states had no limits on union contributions. See Michael J. Malbin \& Thomas L. Gais, The Day After Reform: Sobering Campaign Finance Lessons from the American States 16-17 (1999).

34. See FEC Advisory Op. 1978-10 (1978). Earlier FEC rulings had provided that only hard money could be used to cover the costs of state party voter registration and get-outthe-vote drives intended to benefit both state and federal candidates. See FEC Advisory Op. 1976-72 (1976); FEC Advisory Op. 1976-83 (1976).

35. See FEC Advisory Op. 1979-17 (1979).

36. Prior to 1990, the FEC did not require the parties to report on their soft money accounts, so the numbers in text are only estimates. See Herbert E. Alexander \& Monica Bauer, Financing the 1988 Election 37 (1991). 
in 1991, requiring party committees to report their soft money receipts, expenditures, and transfers, and regulating the allocation of expenses for shared activities between federal and non-federal accounts. ${ }^{37}$ The rules limited the ability of party committees to shelter some funds for shared expenses in non-federal accounts, but " $[t]$ he general effect of the guidelines was ... to give party organizations a clearer sense of how to spend soft money legally, and, at least in some instances, to permit them ... to pay a greater share of their costs with soft money than they had been before." 38

Soft money exploded in the 1990s. In 1991-92, the two national parties raised $\$ 86$ million in soft money, or double the amount for $1987-88 .{ }^{39}$ Soft money accounted for approximately $17 \%$ of total national party receipts in the 1992 election cycle. ${ }^{40}$ By 1995-96, national party soft money receipts had tripled to $\$ 263.5$ million, and accounted for $30 \%$ of total national party income. ${ }^{41}$ In 1997-98, the soft money share of national party income rose to $33 \%$ although actual party soft money receipts declined to $\$ 224.4$ million with the cyclical drop in fundraising tied to the transition from a presidential to a non-presidential election. ${ }^{42}$ National party soft money receipts during this period, however, were nearly five times the $\$ 45$ million in 1988 and more than triple the $10 \%$ soft money share of party receipts in 1993-94, the prior nonpresidential election year. ${ }^{43}$ The 1997-98 election also marked the first time in which soft money played a critical role in congressional elections; in previous years, the primary use of soft money had been to enable presidential candidates participating in the public funding system to evade the spending limits that are a condition for the provision of public funds. Preliminary figures for the 1999-2000 election cycle indicate the dollar volume of soft money is continuing to grow. ${ }^{44}$

37. See 11 C.F.R. § 106.5 (1999).

38. Anthony Corrado, Party Soft Money, in Campaign Finance Reform: A Sourcebook 167, 175 (Anthony Corrado et al. eds., 1997). Even the FEC has acknowledged that "there are ... indications that the allocation rules themselves may have increased the amount of soft money raised by the national party committees." Prohibited and Excessive Contributions; "Soft Money," 63 Fed. Reg. 37722, 37724 (1998) (proposed July 13, 1998).

39. See FEC, Press Release, Political Party Fundraising Continues to Climb (Jan. 26, 1999) (visited on Mar. 2, 2000) <http://www.fec.gov/press/pty3098.htm> (on file with the Columbia Law Review) [hereinafter FEC, Political Party Fundraising Continues to Climb].

40. See id.

41. See id

42. See FEC, Political Party Activity, supra note 21.

43. See id. for the data on party hard money receipts in 1993-94. The data on soft money for that year is from Public Disclosure, Inc., Soft Money Summary (Dec. 28, 1998) (visited on Apr. 4, 2000) <http://www.tray.com/fecinfo/_smrpt.htm> (on file with the Columbia Law Review) [hereinafter Public Disclosure, Inc.].

44. See FEC, Press Release, FEC Releases Fundraising Figures of Major Political Parties-Large Gain in "Soft Money" Contributions (Sept. 22, 1999) <http:www.fec.gov/ press/pytmy99.htm> (on file with the Columbia Law Review) (stating that Republicans and Democrats respectively raised $42 \%$ and $93 \%$ more in soft money during the first six 
The growth in soft money and its expansion into congressional races reflects two developments. First, there is now a substantial number of donors who provide very large soft money contributions. In 1997-98, there were 390 individuals or organizations-including business corporations, labor unions, Indian tribes, and ideological groups-that gave $\$ 100,000$ or more to the soft money accounts of the national political parties. This number of $\$ 100,000+$ donors reflected a $113 \%$ increase from 1993-94, the prior nonpresidential election cycle. Twenty-six donors gave $\$ 500,000$ or more; the top four donors gave more than $\$ 1$ million each. Corporate contributions, which are prohibited by FECA, dominated the soft money growth, with 218 corporations giving more than $\$ 100,000$ in $1997-98$, and sixteen corporations giving more than $\$ 500,000$ in that period. In the prior nonpresidential election cycle, only 96 corporations broke the $\$ 100,000$ mark, and only four gave more than $\$ 250,000$. Thirty-five trade associations also gave $\$ 100,000$ or more in soft money in 1997-98. Wealthy individuals or couples provided most of the other large soft money donations, with 114 individuals or husband-andwife pairs giving $\$ 100,000$ or more, 26 individuals or couples giving $\$ 250,000$ or more, and four giving $\$ 500,000$ or more. ${ }^{45}$

Second, the parties have discovered a major new use for soft money. Instead of being limited, as it was in the 1980 s and early 1990 s, to paying for party overhead, infrastructure improvements, and other indirect support for candidates; soft money is increasingly used to pay for electioneering communications that directly support or attack clearly identified federal candidates. With soft money now used to pay for issue advocacy, the appeal of soft money has grown dramatically. So, too, has the significance of issue advocacy.

3. Issue Advocacy. - The concept of "issue advocacy" grew out of the Supreme Court's effort in Buckley to prevent FECA from unconstitutionally curtailing the discussion of political ideas and issues. The Court construed FECA to apply only to "expenditures for communications that in express terms advocate the election or defeat of a clearly identified candidate." 46 Such expenditures are known in campaign finance jargon as "express advocacy;" all other political communications are called "issue advocacy," although many so-called "issue ads" do not discuss issues at all. ${ }^{47}$ Influenced by a footnote in Buckley, most of the lower federal courts that have considered whether a particular ad constitutes express or issue advocacy have applied the so-called "magic words" test, limiting the definition of express advocacy-and the scope of FECA regulation-to communica-

months of 1999 than during the same period in 1997. By contrast, party hard money receipts were up only $16 \%$ compared to 1997 ).

45. See Public Disclosure, Inc., supra note 43.

46. Buckley v. Valeo, 424 U.S. 1, 44 (1976).

47. See Richard Briffault, Issue Advocacy: Redrawing the Elections/Politics Line, 77 Tex. L. Rev. 1751, 1751 (1999) (discussing issue advertisement that focused on candidate's personal character and not issues). 
tions that literally ask voters to "vote for," "elect," "cast your ballot for," "vote against," or "defeat" a candidate. ${ }^{48}$ Ads that effectively advocate or oppose the cause of a candidate, but do not use the magic words, avoid FECA's restrictions and requirements. ${ }^{49}$

Unlike other uses of soft money, issue ads were initially the province of non-party groups, particularly ideological organizations. In 1995, however, the Federal Election Commission ("FEC") determined that the Republican National Committee ("RNC") could use soft money to partially defray the costs of advertising that combined discussion of issues with criticism of President Clinton by name. ${ }^{50}$ Subsequently, during the 1996 elections, both parties extensively utilized issue ads. The Democratic National Committee ("DNC") undertook a multi-million dollar advertising program to trumpet the accomplishments of the Clinton administration and criticize the Republican Congress without explicitly calling for the election or defeat of particular candidates. So, too, the RNC spent millions to pay for issue ads in support of the Dole campaign. These party issue ads effectively eviscerated the presidential public funding spending limits. ${ }^{51}$ One early study estimated that the parties spent $\$ 68$ million on issue ads in the 1996 election cycle, ${ }^{52}$ thereby accounting for nearly half of all issue ad spending in that election. Another scholar recently estimated that major party issue ad spending in 1995-96 equaled nearly $\$ 110$ million. ${ }^{53}$ Similarly, party issue ad spending amounted to between $\$ 90$ million and $\$ 110$ million during the $1997-98$ election cycle. ${ }^{54}$ What these figures mean is that party issue ad spending is now comparable to, and possibly greater than, the total of party spending in donations to candidates, coordinated spending, and independent spending. ${ }^{55}$

48. Id. at $1754-59$.

49. See id. at $1759-60$.

50. See FEC Advisory Op. 1995-25 (1995).

51. See Robert Biersack \& Melanie Haskell, Spitting on the Umpire: Political Parties, the Federal Election Campaign Act, and the 1996 Campaigns, in Financing the 1996 Election 155, 177 (John C. Green ed., 1999).

52. Deborah Beck et al., Issue Advocacy Advertising During the 1996 Campaign 3, 34, 55 (1997).

53. See Paul S. Herrnson, Financing the 1996 Congressional Elections, in The State of the Parties: The Changing Role of Contemporary American Parties, supra note 32, at 95, 122 [hereinafter Herrnson, Financing the 1996 Congressional Elections] (reporting that DNC and the Democratic congressional committees spent $\$ 60$ million on issue ads in 1995-96, while the RNC and Republican congressional committees spent $\$ 49$ million).

54. Jeffrey D. Stanger \& Douglas G. Rivlin, Issue Advocacy Advertising During the 1997-1998 Election Cycle 1-4 (1998) <http://appcpenn.org/issueads/report.htm> (on file with the Columbia Law Review).

55. Party-coordinated and independent expenditures in the 1996 presidential election came to $\$ 19.2$ million. See Anthony Corrado, Financing the 1996 Presidential General Election, in The State of the Parties: The Changing Role of Contemporary American Parties, supra note 32, at 63, 75. Party contributions to candidates, coordinated expenditures, and independent expenditures in the 1996 congressional elections came to $\$ 70.9$ million. See Biersack \& Haskell, supra note 51, at 163 . Total party contributions to, coordinated expenditures with, and independent expenditures concerning federal 
By engaging in issue advocacy, the parties have vastly expanded their ability to use soft money. No longer limited to building infrastructure or to efforts ostensibly aimed at non-federal candidates, soft money can now be deployed directly to pay for ads that aid a party's federal candidates. Rapidly growing soft money collections-increasingly solicited by federal officials, led by President Clinton-and the expansive new use for soft money dramatically reinforced each other over the last two election cycles.

The FEC's 1995 advisory opinion did place one important limit on the use of soft money to fund issue advocacy: The opinion treated party issue advocacy as a form of mixed federal/non-federal activity comparable to administrative overhead or "generic voter drive costs." 56 Under FEC regulations, such mixed activities, which by their nature support both federal and nonfederal candidates, must be financed by a specified combination of hard and soft money. For the national party committees, mixed spending must be funded $60 \%$ by hard money and $40 \%$ by soft money in nonpresidential election years, and $65 \%$ by hard money and $35 \%$ by soft money in presidential election years. ${ }^{57}$ For state parties, the hard/soft allocation is based on the federal share of the total number of federal and state offices on the state ballot. ${ }^{58}$ In 1998, however, two party committees sued the FEC, asserting that issue advocacy is entirely beyond the scope of election regulation, so that any limit on the use of soft money to fund issue advocacy is unconstitutional. The parties failed to obtain injunctive relief in time for the 1998 elections, but the suit is still pending. ${ }^{59}$ If the party committees prevail, party issue advocacy is likely to surge, and with it, the demand for party soft money.

candidates in $1997-98$ came to $\$ 40.8$ million. See FEC, Political Party Fundraising Continues to Climb, supra note 39.

56. See FEC Advisory Op. 1995-25 (1995). In its request for an advisory opinion permitting the use of soft money to fund issue advocacy advertising, the Republican National Committee had urged that such acts were party "administrative expenditures." Party administrative expenditures are subject to FEC rules requiring the party to allocate its expenses between federal and non-federal costs. The RNC did not contend that party issue ads were completely beyond the scope of FECA regulation. The FEC determined that the costs of the ads were either administrative expenditures or generic vote drive expenditures. The Commission did not have to determine which category of expenditure covered issue ads since both categories were subject to the same federal/non-federal allocation formula.

57. See 11 C.F.R. $\S 106.5$ (b) (2) (2000).

58. As there are typically far more state than federal offices up for election in any given state, the state parties may fund most of their issue advocacy spending with soft money. To take advantage of this, the national party committees transferred tens of millions of dollars of soft money to the state parties, so that the latter could use their greater soft money allocation to pay for issue ads and other shared federal-nonfederal expenses. See Jill Abramson \& Leslie Wayne, Democrats Used the State Parties to Bypass Limits, N.Y. Times, Oct. 2, 1997, at A1; Biersack \& Haskell, supra note 51, at 179-81.

59. Republican Nat'l Comm. v. FEC, No. 98-5263, 1998 U.S. App. LEXIS 28505, at *3 (D.C. Cir., Nov. 6, 1998) (affirming district court order denying preliminary injunction 


\section{Party Money and the Buckzey Doctrine}

\section{A. The Constitutional Issues and the Conflicting Models of the Parties' Campaign Role}

1. Independent Spending. - Together party independent spending, party soft money, and party issue advocacy have undermined many of the basic elements of FECA, specifically the dollar and source limits on campaign contributions, the limits on party support for candidates, and the spending limits on coordinated expenditures that are built into the presidential public funding system. These same practices would be equally subversive of any public funding program Congress might adopt for congressional elections, and of state-level public funding initiatives for state elections.

The Buckley doctrine appears to raise serious constitutional objections to any legislative efforts to curtail party independent spending or party issue advocacy. The distinction between coordinated spending, which is treated as a contribution and may be subject to limitation, and independent spending, which is immune from limitation, is a central element of Buckley. ${ }^{60}$ Moreover, in Colorado Republican, a Supreme Court plurality specifically determined that parties are capable of independent spending and that such party spending is entitled to the same constitutional protection as independent spending by individuals or PACs. ${ }^{61}$ So, too, the line between express advocacy and issue advocacy is central to Buckley, ${ }^{62}$ and there is nothing in the Court's campaign finance cases indicating that party issue ads are less protected than the issue ads of other organizations. ${ }^{63}$

Legislative restrictions on soft money would appear to be less vulnerable to constitutional challenge. Soft money involves contributions to the parties, rather than spending by the parties, and a fundamental element

against application of FEC soft money allocation regulation to party issue advocacy expenditures).

60. See Buckley v. Valeo, 424 U.S. 1, 46-47 (1976).

61. See Colorado Republican Fed. Campaign Comm. v. FEC, 518 U.S. 604, 613-23 (1996).

62. See Buckley, 424 U.S. at 41-44, 76-80; see also FEC v. Massachusetts Citizens for Life, Inc., 479 U.S. 238, 248-50 (1986) (citing Buckley).

63. The ads in Colorado Republican were arguably issue advocacy since they criticized a candidate's record but did not expressly call for his defeat. Indeed, the district court held that the ads were not express advocacy. See FEC v. Colorado Republican Fed. Campaign Comm., 839 F. Supp. 1448, 1454 (D. Colo. 1993). The Tenth Circuit held that the ads contained an "electioneering message" within the meaning of an FEC advisory opinion that provided that such messages by parties are subject to FECA's limits on coordinated spending. FEC v. Colorado Republican Fed. Campaign Comm., 59 F.3d 1015, 1021-22 (10th Cir. 1995) (citation omitted). The court suggested that the concept of express advocacy could be interpreted more broadly when applied to party speech, but its opinion also assumed that parties are incapable of engaging in independent expenditures. See id. at 1024. The latter assumption was, of course, reversed by the Supreme Court. The Supreme Court did not discuss whether the Colorado Republican ads might be issue advocacy. 
of Buckley, most recently reconfirmed by Nixon v. Shrink Missouri Government $P A C,{ }^{64}$ is that contributions present special dangers of corruption that warrant limitation. Moreover, the principal providers of soft money are corporations and the Court has specifically upheld bans on the use of corporate treasury funds in candidate elections. ${ }^{65}$

Nevertheless, constitutional arguments have been raised against legislation that would curtail soft money. First, Professor Bradley A. Smith has argued that soft money used to fund issue advocacy is constitutionally exempt from limitation since issue advocacy, by definition, is political speech immune from regulation. ${ }^{66}$ In his view, as issue advocacy spending is protected from regulation by the First Amendment, the contributions that fund such spending must be constitutionally protected as well. Second, going beyond issue advocacy, the case for limiting soft money donations to the parties relies on the foundational assumption that there is something corrupting about party spending. The need for a danger of corruption to justify a contribution limitation was made clear in Citizens Against Rent Control v. City of Berkeley, where the Court relied on its previous determination that spending on ballot propositions raises no possibility of corruption (as there was no candidate to corrupt) to hold unconstitutional an ordinance restricting donations to committees that support or oppose such ballot propositions. ${ }^{67}$ If party spending cannot corrupt, then, under his logic, contributions to parties may not be limited either. In Colorado Republican, several members of the Supreme Court denied that party support for candidates presents a danger of corruption within the meaning of Buckley. Instead of joining the plurality and protecting the party ads in that case as independent expenditures, Chief Justice Rehnquist and Justices Kennedy, Scalia, and Thomas would have invalidated FECA's limits on party coordinated expenditures. ${ }^{68}$ On remand, a district judge did exactly that. ${ }^{69}$ Although these opinions focused on coordinated spending limits, they also raise questions about the limits on party contributions to candidates - since both FECA and Buckley treat

64. 120 S.Ct. 897 (2000).

65. See Austin v. Michigan Chamber of Commerce, 494 U.S. 652, 652-53 (1990); FEC v. National Right to Work Comm., 459 U.S. 197, 197 (1982).

66. See Bradley A. Smith, Soft Money, Hard Realities: The Constitutional Prohibition of a Soft Money Ban, 24 J. Legis. 179, 196-99 (1998). In February 2000, President Clinton nominated Professor Smith to be a member of the Federal Election Commission.

67. National Right to Work, 454 U.S. 290, 298-99 (1981).

68. See Colorado Republican Fed. Campaign Comm. v. FEC, 518 U.S. 604, 626-31 (1996) (Kennedy. J., joined by Rehnquist, C.J. and Scalia, J. concurring in the judgment and dissenting in part); id. at 644-48 (Thomas, J. joined by Rehnquist, C.J. and Scalia, J. concurring in judgment and dissenting in part).

69. FEC v. Colorado Republican Fed. Campaign Comm., 41 F. Supp. 2d 1197, 1210-13 (D. Colo. 1999) (noting that "communications via coordinated expenditures implicate core First Amendment rights"). As this Article was going to press, a divided panel of the Tenth Circuit affirmed the district court's decision. See Colorado Republican Fed. Campaign Comm. v. FEC, No. 99-1211, 2000 WL 554688 (10th Cir. May 5, 2000). 
coordinated expenditures and contributions as legally equivalent-and, ultimately, perhaps the limits on contributions to the parties as well.

Strikingly, the constitutional challenges to limits on party money flow from diametrically opposing visions of the parties and, especially, of the relationships among parties and candidates. On the one hand, the defense of party independent spending and party issue advocacy assumes a sharp separation between the parties and their candidates. If a party committee functioned as a candidate's campaign organization, then all spending by that committee, whether or not technically coordinated with a candidate, would be considered coordinated spending. Similarly, if a party committee served as an arm of the candidate's campaign organization then all its advertising, even ads lacking the magic words of express advocacy, would be express advocacy for constitutional purposes just as all campaign expenditures by a candidate are considered to be express advocacy even if the candidate's ads do not say "vote for me" or "vote against my opponent." Strong constitutional protection of such activity assumes that parties are sharply distinct from their candidates, resembling in this way all other campaign intermediaries. In effect, the argument against limits on party independent spending and party issue advocacy assumes that parties are like PACs and are entitled to the same protections afforded to PACs.

By contrast, the constitutional argument against limits on direct party support for candidates, and the implicit challenge to limits on donations to parties, assumes that parties are quite different from other campaign finance intermediaries. Parties, unlike PACs, are considered to be uniquely close to, if not identical with, their candidates. The close party-candidate relationship is said to eliminate the possibility of partycandidate quid pro quos so that party participation in campaigns cannot present danger of corruption. Indeed, limiting party support for candidates would be like limiting candidates' support for their own campaigns, which is unconstitutional under Buckley.

Both critiques of limiting party money cannot be right. Indeed, I believe both are wrong. Although, as noted in Part I, FECA to some extent models its regulation of parties on its treatment of PACs, the major political parties are not PACs. To mechanically apply constitutional distinctions developed in the PAC context makes little sense and is a recipe for wholesale evasion of the campaign finance laws. Further, by closely linking private donors, party committees, and officeholders, party fundraising practices directly implicate the corruption concerns that Buckley placed at the center of our campaign finance regime.

\section{B. Party Spending and the Limits of the PAC Model}

1. Independent Spending. - The principal decision illustrating the parties-as-PACs model is the plurality opinion of Justice Breyer, joined by Justices O'Connor and Souter, in Colorado Republican, which found that party committee spending, like PAC spending, can be subject to limits 
only if it is in fact coordinated with a candidate's campaign. ${ }^{70}$ Relying on earlier cases that had invalidated limits on independent expenditures by PACs, ${ }^{71}$ the plurality could "not see how a provision that limits a political party's independent expenditures can escape their controlling effect." 72

But the justifications for constitutional protection for PAC or individual spending are not implicated by spending by party committees. First, individuals and non-party organizations participating in a campaign may have interests other than, or in addition to, the election of the candidate they are backing or the defeat of the candidate they are attacking. They may use their expenditures to highlight an issue in order to send a message, or to persuade the voters to send a message, on that issue. It may be as important to them to make the election a referendum on abortion, or to emphasize that their opposition to a candidate stems from her position on term limits, as to express a position on which candidate should be elected. Their critical issues may include matters candidates prefer to ignore. Indeed, by airing certain messages an independent committee's advertising may be at odds with the campaign strategy of the very candidate it is backing.

The major parties, by contrast, do not have any electoral agenda other than election of their candidates. "The defining mission focus of political parties in the contemporary era is to elect candidates to office." ${ }^{73}$ Major party advertising expressly advocating the election or defeat of a candidate-the type of advertising funded by independent spending-is not intended to raise issues that differ from those advanced by the party's candidates, or to elect candidates with a particular policy mandate. Its goal is, simply, to elect candidates affiliated with the party.

Second, Buckley found, and FEC v. National Conservative Political Action Committee ("NCPAC") ${ }^{74}$ reiterated, that independent expenditures raise little danger of a candidate-financial supporter quid pro quo, which is the constitutional basis for the power to restrict contributions, because the "absence of prearrangement and coordination ... undermines the value of the expenditure to the candidate." ${ }^{5}$ This might be true for an independent expenditure by an individual or interest group that is institutionally distinct from the candidate. In the absence of an ongoing rela-

70. See Colorado Republican, 518 U.S. at 613-23.

71. See id. at 615 (citing Buckley and FEC v. National Conservative Political Action Comm., 470 U.S. 480 (1985), for proposition that "restrictions on independent expenditures . . 'represent substantial restraints on the quantity and diversity of political speech'”).

72. Id.

73. William Crotty, Political Parties in the 1996 Election: The Party as Team or the Candidates as Superstars?, in The Parties Respond: Changes in American Parties and Campaigns 203 (L. Sandy Maisel, ed., 1998). See also Herrnson, Party Campaigning in the 1980 s, supra note 9 , at 8 ("The principal aim of American political parties has always been to elect candidates to public office.").

74. 470 U.S. 480 (1985).

75. Buckley v. Valeo, 424 U.S. 1, 47 (1976). 
tionship between candidate and independent supporter, the supporter's advertising could hit the wrong themes, or be redundant rather than supplement candidate spending. But there will typically be preexisting ties between the party organization and the candidate who holds the party's nomination.

Party committees frequently aid candidates in hiring campaign managers, consultants, media and pollsters, so that parties and their committees often engage the services of the same political professionals. Party committees provide their candidates with issue and opposition research and poll and focus group data, and they assist candidates with their fundraising. ${ }^{76}$ Party committees and candidates share pollsters, campaign strategists, and media consultants; campaign professionals shuttle back and forth among party committees, candidate committees, and consulting firms. Even when they do not sit down to discuss the placement or content of a specific ad, parties and their candidates are structurally integrated, not independent. ${ }^{77}$ As a result, party efforts on behalf of a candidate are likely to be quite valuable to the candidate even in the absence of formal coordination.

The ability of parties to combine a close structural relationship with a candidate while maintaining the notional independence of a particular advertising campaign is nicely illustrated by the recent federal district court decision in Republican Party of Minnesota v. Pauly. ${ }^{78}$ The Minnesota Republican Party provided state candidates with "'meaningful and helpful' service and 'direct support," kept in "'close contact' with 'elected officials and statewide campaigns," " “'work[ed] directly with Republican candidates on issue research,' 'develop[ed] campaign plans,' and 'manage[d] the scheduling of candidate and party activity." "79 On "numerous occasions" candidates who had been endorsed by the party attended party fundraisers, and the party encouraged its candidates to attend biweekly "coordinating meetings" at party headquarters. The party also made direct contributions to its candidates. ${ }^{80}$ But when the party took out its own advertising in support of its nominees, the party officials responsible for the ads avoided direct contact with the candidates. As a result, the party's ads were considered to be independent expenditures, not subject to limitation. ${ }^{81}$ Although the district court found the "record in this case [to be] replete with examples of cooperation," there was no

76. See, e.g., Herrnson, Financing the 1996 Congressional Elections, supra note 53, at 100 (discussing the involved role of parties in Senate and House elections).

77. See Jonathan Bernstein \& Raymond J. La Raja, Independent Expenditures and Partisanship in House Elections 15-16 (1999) (unpublished paper prepared for delivery at 1999 Annual Meeting of the American Political Science Association, Sept. 2-5, 1999) (on file with the Columbia Law Review) (concluding that "outsider ads sponsored by political parties are signs of party integration").

78. 63 F. Supp. 2d 1008 (D. Minn. 1999).

79. Id. at $1010-11$ (citation ommited).

80. Id. at 1012.

81. See id. at 1016 . 
evidence of "actual coordination" of the particular expenditures in question with candidates. ${ }^{82}$

Certainly, parties are organizationally distinct from their candidates, and it is technically possible, as Colorado Republican suggested, for a party committee to support a candidate by engaging in spending that is not coordinated with the candidate's campaign. But the party's relationship to its candidate is very different from that between a PAC and a candidate the PAC is backing. The party includes its candidate. The candidate is typically a member of the party, has been active in the party, and, once nominated, bears the party label, uses the party's place on the ballot, and necessarily benefits from the loyalty and support of party activists. In this way, candidates are far more tightly linked to their respective parties than they are to other politically active organizations that may engage in independent spending.

But, as Pauly reveals, the judicial notion of party independent spending pays scant attention to the actual relationships among parties and candidates. Given the structural integration and shared institutional interests of parties and candidates, the doctrine of party independent spending makes little sense. Certainly, the notion of independence should be construed far more narrowly, and the presumption of coordination should be far stronger, when party spending is at issue.

2. Issue Advocacy. - The application of the express advocacy/issue advocacy distinction to the parties implicates similar concerns. As previously noted, this distinction derives from the Supreme Court's recognition that some doctrinal means is needed to permit regulation of election-related spending while simultaneously preserving the fundamental First Amendment value of immunizing non-election-related political speech from regulation. The line the Court drew between express advocacy and all other political speech reflects the desire for a test that is both crisp, thereby avoiding vagueness and the chilling effect that can result from vague regulation, and narrow, thus minimizing any interference with other political speech.

The Court's particular distinction between express advocacy and other speech may make some sense with respect to individuals and groups, such as PACs, that participate in politics in order to advance certain issue agendas, protect certain interests, or affect public policy. For them, election-related activity may be only one of a number of techniques-including legislative lobbying, the use of op-eds or think tank research targeting opinion leaders, advertising aimed at influencing public opinion more generally, or grass-roots organizing used to affect the political process. Some narrow definition of election-related speech is necessary to protect these other forms of political speech and activity, which can have indirect effects on elections, from the constraints of FECA. The narrow express advocacy test enables such actors to discuss

82. Id. 
political issues and policy goals by reference to particular elected officials and candidates without fearing that they will be subject to FECA's reporting requirements and contribution and spending rules. The current definition of express advocacy may be too narrow-and may enable many plainly election-related ad campaigns to evade FECA's rules and requirements-but the need for a definition of election-related speech that provides ample protection for issue speech is apparent.

The major political parties, particularly the national and congressional campaign committees, are, however, quite different from other politically active groups. Party committee spending aims almost exclusively at promoting the election of party candidates to office and thereby securing or maintaining party political power. This is not to say that the major parties have no interest in ideology, or that they do not have the same right as other organizations to discuss issues. To the contrary, the two great national parties were founded for ideological reasons, and contemporary party activists often have strong ideological bents. No doubt many people who choose to become active in party organizations do so in the belief that by helping their party win power they are advancing their own policy views. Party spending that is exclusively about issues is rightly entitled to the same constitutional protection that non-election-related spending by other groups or individuals enjoys. But most party spending is aimed at electing party candidates. When PACs and other politically active groups combine discussions of issues and candidates, it may not be clear whether they are doing so to advance their issues agenda or elect candidates, but when parties couple issue discussions with references to candidates their goal is almost certainly the election of their candidates.

Indeed, in the last two election cycles, the content of party issue advertising was often indistinguishable from both party express advocacy ads and the candidates' own ads. As one recent study of campaign ads found, "some of the Democratic Party issue ads that helped Bill Clinton in 1995 used the same film clips and some of the same voiceovers as the Clinton campaign ads-indeed, they were distinguishable only by their failure to call explicitly for the president's reelection." 83 Some ads that appeared in 1996 were run both as "express" ads paid for by the presidential campaigns and as "issue" ads paid for by party committees. "With the exception of a 'tag' line, these ads were exactly the same." 84 A content analysis of party issue ads and candidate ads in one 1996 Senate race found that the ads were quite similar. Both contained discussions of campaign issues, with "only small differences in the extent to which candidate ads and party ads highlight issues." 85 Both avoided use of the "magic words" of express advocacy and, instead made only subtle or indirect ref-

83. Wesley Joe \& Clyde Wilcox, Financing the 1996 Presidential Nominations: The Last Regulated Campaign?, in Financing the 1996 Election, supra note 45, at 37, 61.

84. Biersack \& Haskell, supra note 51, at 177.

85. Herrnson \& Dwyre, supra note 32, at 98. 
erences, if any references at all, to the upcoming election. ${ }^{86}$ Both used the same visual and audio production techniques. Party ads used "slowmotion, black-and-white, blurry footage," and "grainy and fearful images" of candidates of the other party, and sought to visually link those candidates with undesirable groups, like criminals or gang members. ${ }^{87}$ "The use of such a technique by the parties in issue advocacy ads gives those ads a distinctly campaign-like flavor, further confirming their intent to influence the outcome of an election rather than merely to educate voters about some policy issue." 88

Party issue ad spending is, in practice, not a means for politically active, independent citizens to increase the discussion of issues in public life, but rather an integral part of candidate-election strategies. The purpose of party issue advocacy is simply to avoid the spending limits on publicly funded presidential candidates and on coordinated expenditures for congressional candidates, and to spend money obtained in contributions that do not comply with FECA's restrictions. In reports released in the fall of 1998, FEC auditors found that the DNC and the Clinton-Gore ' 96 campaign had worked together on the production and placement of television ads paid for by the DNC, and that the party and the candidates' committee shared a standard form memorandum for authorization of production and purchase of air time for media advertising: "One section of this memorandum states 'The cost will be allocated a $\%$ for the DNC and _\% for Clinton-Gore ' 96 .' The next line states 'attorneys to determine.' "89 The FEC general counsel found that it was "difficult to distinguish between the activities of the DNC and the [Clinton] Primary Committee with respect to the creation and publication of the media advertisements at issue." ${ }^{0}$ FEC auditors also found that the RNC paid more than $\$ 18$ million directly and through Republican state committees on behalf of the Dole campaign for ads that were aired between April and August 1996, a period in which Dole was bumping up against the spending ceiling he had accepted as a condition for receiving

86. Id. at 94-96. Both candidates and parties appear to have absorbed a central lesson of modern advertising, that indirect appeals can be far more effective than direct exhortation to buy a product. As Justice Ann Walsh Bradley of the Wisconsin Supreme Court recently observed,

Few advertisements will directly say 'Buy Nike rather than Reebok' or 'Drink Maxwell House coffee.' Be they in the print or electronic media, advertisements normally do not include a call for action or use 'magic words' to relay their message. Yet every reader, listener, or viewer knows that 'Less filling, tastes great' is an unambiguous exhortation to purchase a particular type of Miller beer, and 'They're Gr-r-reat' is Tony the Tiger's unambiguous appeal to buy a box of sugarcoated corn flakes.

Elections Bd. of Wis. v. Wisconsin Mfrs \& Commerce, 597 N.W.2d 721, $742-43$ (Wis. 1999).

87. Herrnson \& Dwyre, supra note 32, at 99.

88. Id. at 99 .

89. FEC, Report of the Audit Division on Clinton/Gore '96 Primary Committee, Inc. 18 (1998).

90. Id. at 108 . 
public funding. ${ }^{91}$ In 1998, again, party issue ads "reinforced the themes and messages of their candidates." 92 When skillfully done, issue ads demonstrated "seamless party/candidate communication" on such topics as taxes, drugs, and education. ${ }^{93}$ "This consistency assisted voters [to] remember the candidate's agenda." 94

To be sure, some advertising broadcast or published by party committees can be just about issues. As previously indicated, such speech must be protected from governmental regulation. But, as with the coordinated/independent distinction, the intensive focus of party spending on election campaigns and the close, ongoing institutional connection between party candidates and party campaign committees suggests that in the party context, Buckley's goals of regulating election-related speech while protecting issue speech may be more effectively vindicated by a definition of election-related speech that is broader than would be constitutionally acceptable for speech by PACs, other non-party groups, or politically-active individuals. Such a shift is necessary if the other goals of campaign finance law-restrictions on large donations, the prohibition on corporate and union contributions, the spending ceilings that are part of public funding - are to be protected from the issue advocacy end-run around FECA.

\section{Parties and Corruption: The Contributor-Party-Candidate Relationship}

The claim that party money does not present a danger of corruption poses a potentially far more serious constitutional objection to regulating party money than does the analogy between parties and PACs. Under the view of parties-as-PACs, party coordinated expenditures may be limited and express advocacy must be funded by hard money. But if party money presents no danger of corruption, then there is no longer any basis for limiting either donations to parties or the financial support provided by parties to their candidates.

The argument that party money cannot be corrupting assumes two forms. The first claims that the tight ties linking a party to its candidates-the very ties that distinguish parties from PACs and make the notion of party independent spending so implausible-prevent the parties from exerting a corrupting influence on their candidates. This argument is theoretically shaky, but may be correct in practice. The second recognizes that parties get their money from private donors who may wish to channel money to specific candidates in order to evade FECA's limits on

91. See FEC, Report of the Audit Division on the Dole for President Committee, Inc. (Primary) 16-17, 34-37, 46 (1998).

92. David B. Magleby \& Marianne Holt eds., Outside Money: Soft Money \& Issue Ads In Competitive 1998 Congressional Elections (1998) <http://www.byu.edu/ outsidemoney/mono.htm> (unpublished report of a grant funded by the Pew Charitable Trusts, on file with the Columbia Law Review).

93. Id.

94. Id. 
direct donations to candidates, but argues that the large number of donors to and variety of interests represented by a party serve to dilute any corruptive potential. This argument is attractive in theory but is seriously undermined by current campaign finance practices.

1. Party Influence Over Candidates. - A strong version of the argument that a party is incapable of corrupting its candidates was articulated by Justice Kennedy in his Colorado Republican separate opinion. Justice Kennedy claimed that there is "a practical identity of interests" between party and candidate such that party spending in support of a candidate, including spending coordinated with the candidate, "is indistinguishable in substance from expenditures by the candidate or his campaign committee. ${ }^{95}$ As a result, limiting party support for its candidate would be like limiting the candidate's own campaign spending-which Buckley held to be unconstitutional. ${ }^{96}$ Alternatively, given " $[t]$ he party's form of organization and the fact that its fate in an election is inextricably intertwined with that of its candidates," 97 a party could no more corrupt its candidates than it could corrupt itself. Limiting party support for candidates, then, would be analogous to limiting a candidate's ability to use her personal wealth to fund her campaign. Buckley, however, invalidated the FECA provision that would have limited candidates' use of personal funds precisely because the latter presented no danger of corruption. ${ }^{98}$

Justice Thomas, writing for himself, Chief Justice Rehnquist, and Justice Scalia in their separate Colorado Republican opinion, advanced a less extreme version of this argument. He argued that even if a party committee uses its funds to influence a candidate, there is nothing wrong-nothing "corrupting" - about that: "The very aim of a political party is to influence its candidate's stance on issues and, if the candidate takes office or is reelected, his votes." ${ }^{99}$ A party's exercise of influence over its candidates and officeholders is not "'subversion of the political process,' " but "successful advocacy of ideas in the political marketplace and representative government in a party system." 100

Other judges have expressed similar views about the positive effects of party influence on candidates. In 1981, when a unanimous Supreme Court upheld the validity of party agency agreements, ${ }^{101}$ it observed approvingly that such agreements could lead to a more effective use of party resources in support of party candidates, which "may encourage candi-

95. Colorado Republican Fed. Campaign Comm. v. FEC, 518 U.S. 604, 630 (1996) (Kennedy, J., joined by Rehnquist, C.J. and Scalia, J., concurring in the judgment and dissenting in part).

96. See id. (citing Buckley's invalidation of FECA's limits on candidate's campaign expenditures).

97. Id.

98. See Buckley v. Valeo, 424 U.S. 1, 53 (1976).

99. Colorado Republican, 518 U.S. at 646.

100. Id. (citation omitted).

101. See supra text accompanying note 20 for a description of party agency agreements. 
date loyalty and responsiveness to the party." 102 In striking FECA's caps on coordinated spending in the Colorado Republican remand, moreover, District Judge Nottingham concluded that party use of coordinated expenditures to influence candidates could not be viewed as "an attempt to exert improper influence." 103 In a recent decision, the Tenth Circuit agreed that there is "nothing pernicious" about a party's efforts at "shaping the views of its candidates." 104

Many political scientists also emphasize the benefits of greater party influence over candidates. They argue that greater party cohesion could facilitate concerted action across the separate branches of government and make the party labels on candidates more meaningful to voters. This would make it easier for voters to judge the record of the party in power, compare the programs of competing parties, and cast ballots based on policies rather than candidate personalities. Indeed, a group of distinguished political scientists, writing as the Committee for Party Renewal, submitted an amicus brief in Colorado Republican urging that "[p]olitical party support is not corruptive. ..."105

The argument that parties, by definition, cannot corrupt their candidates is debatable in theory. Certainly, Justice Kennedy notwithstanding, parties and candidates are not literally identical. Party committees and candidates can differ over campaign strategies and policy issues. Party committees, like other campaign donors, could seek to leverage their funds to induce a candidate to take certain positions on pending legislative issues, to harmonize her campaign with national party themes, or even to hire certain campaign professionals. Party committees might try to do this in order to attract more contributions and other forms of support for the party from PACs, individuals, and politically active ideological or special interest groups. Because a national party committee is concerned with a wide range of elections across the country, and with securing power at the national level, rather than with any one candidate's particular fate, the party's interests might conceivably diverge from those of a candidate in a particular race.

Nor are party efforts to influence candidate issue positions necessarily desirable given the longstanding tradition in our political culture of looking at party organizations and party bosses with skepticism, if not fear. From Madison's condemnation of faction, to the Progressive Era drive to use the primary to break the hold of party machines, ${ }^{106}$ to con-

102. FEC v. Democratic Senatorial Campaign Comm., 454 U.S. 27, 42 (1981).

103. FEC v. Colorado Republican Fed. Campaign Comm., 41 F. Supp. 2d 1197, 1212 (D. Colo. 1999).

104. Colorado Republican Fed. Campaign Comm. v. FEC, No. 99-1211, 2000 WL 554688 , at $* 10$ (10th Cir. May 5, 2000).

105. Brief Amicus Curiae Committee for Party Renewal at 16, Colorado Republican Fed. Campaign Comm. v. FEC, 518 U.S. 604 (1996) (No. 95-489).

106. See, e.g., Epstein, supra note 24, at 155-56 (describing the direct primary as the "institutionalized means" of pursuing politics in "a civic culture that is broadly hostile to party organizational control"). 
temporary public sentiments, caught in opinion polling, which indicate a preference for voting the candidate and not the party, ${ }^{107}$ there is a strong commitment in the American system to the independence of candidates and officeholders from party control. Justice Stevens, in his Colorado Republican dissent, adverted to this when he voiced concern that "the party-or the persons who control the party-will abuse the influence it has over the candidate by virtue of its power to spend." 108 The emergence of candidate-centered politics in the twentieth century is at least in part a reflection of this popular sentiment and of institutional arrangements, such as the direct primary and the primary open to non-party voters, intended to implement that sentiment.

Still, in practice, those who argue that party money does not present a serious danger of undue party influence over candidates may be right. Studies of party campaign committees have found that the parties strive not to influence or control their candidates, but rather to serve them and thereby help to elect them. ${ }^{109}$ A national party committee typically has "little interest in ideological 'litmus tests' and instead provides assistance to candidates based on their chance of winning. Candidate assistance is apportioned according to fulfillment by the candidates of non-policy criteria, such as individual fund-raising levels and favorable polling numbers." 110 This candidate-election focus of party organizations is connected to some of the central characteristics of contemporary politics:

107. See Martin P. Wattenberg, The Rise of Candidate-Centered Politics: Presidential Elections of the 1980s 34 (1991) ("Most pervasive is the belief that one should vote for the candidate, not the party."); see also State v. Alaska Civil Liberties Union, 978 P.2d 597, 626 (Alaska 1999) ("The natural tendency of successful candidates who receive unlimited contributions from a party would be to reduce independent consideration of issues and adhere to positions taken by the party itself.").

108. Colorado Republican Fed. Campaign Comm. v. FEC, 518 U.S. 604, 648 (1996) (Stevens, J., dissenting, joined by Ginsburg, J.); see also FEC v. National Republican Senatorial Comm., 761 F. Supp. 813, 821-22 \& n.12 (D.D.C. 1991), rev'd on other grounds, 966 F.2d 1471 (D.C. Cir. 1992). Here, the Court found that it is "entirely plausible" that spending limits on party committees "serve[ ] the anti-corruption purposes identified by Congress and approved by the Supreme Court in Buckley" and that "Congress, by setting contribution limits from the parties to candidates has apparently concluded that too much responsiveness to the parties, if obtained by unrestricted contributions, is undesirable.")

109. See, e.g., John H. Aldrich, Why Parties? The Origin and Transformation of Political Parties in America 269-74 (1995) (describing the "rise of the party in service to its candidates"); John F. Bibby, State Party Organizations: Coping and Adapting to Candidate-Centered Politics and Nationalization, in The Parties Respond: Changes in American Parties and Campaigns 24 (L. Sandy Maisel ed., 1998).

According to Frank Sorauf, "the party as funder rarely, if ever, asks questions of program or issue commitment of those it helps; the question is electability, not loyalty to party programs or issue positions." Frank J. Sorauf, What Buckley Wrought?, in If Buckley Fell: A First Amendment Blueprint for Regulating Money in Politics 11, 24 (E. Joshua Rosenkranz ed., 1999).

110. Robert G. Boatright, "You Don't Know Me, but Here I Am": Congressional Candidates and Party Strength, in The State of the Parties: The Changing Role of Contemporary American Parties, supra note 32, at 320, 323. 
the relative weakness of partisanship within the electorate, the closeness of the conflict between the major parties over the control of national political institutions, and the increased salience of partisanship within the government.

With party loyalty in the electorate declining, partisan control of the Presidency and Congress up for grabs, and the determination of party control having a major impact on government operations, party organizations-particularly the Senate and House campaign committees, which are actually composed of elected officials-are constrained to make winning, rather than ideological purity their primary, if not exclusive, goal. ${ }^{111}$ Congressional party committees participate in elections to protect or gain seats for their party in their respective legislative chamber so that the party can organize the chamber and reap the benefits flowing from control over committee assignments and the legislative agenda. Their interest in legislative power binds them far more tightly to their candidates than ideological affinity or voting records links ideological groups to the candidates they back. Ideological groups can try to use their power to grant or withhold funds to influence officeholder actions. But with the success of party committees closely tied up with the election of party candidates, it is unlikely-as studies of party committees showthat these committees will use their funds to advance any goal other than the electoral success of their candidates.

To be sure, if the current limits on party spending were invalidated-or the growing role of party spending outside of FECA were to render the statutory limits completely irrelevant ${ }^{112}$ - the potential for party organizations to exert influence over party officeholders might grow. ${ }^{113}$ But at the moment, the danger that party officials will use their

A study of state legislative campaign committees ("LCCs") also found that "there is little evidence to suggest LCC resources are used as a reward or punishment for legislative behavior." Daniel M. Shea, Transforming Democracy: Legislative Campaign Committees and Political Parties 29 (1995); see also Gierzynski, supra note 21, at 122 ("[T]here is no attempt to increase party cohesion by distributing resources on the basis of party loyalty or ideology.").

111. This is nicely illustrated by the strategic advice the National Republican Campaign Committee gave to a Republican Congressional candidate in 1990 to vote against Republican President Bush's tax plan, and the assistance it gave to the House candidate in preparing ads that highlighted the candidate's opposition to his own party's president. See Kolodny, supra note 25, at 185.

112. Cf. Mariani v. United States, 80 F. Supp. 2d 352, 420-21 (M.D. Pa. 1999) (certifying to appellate court the question of whether FECA's ban on corporate contributions in federal elections is unconstitutional "in the context of the presently existing law that otherwise permits corporations to expend unlimited amounts of corporate treasury funds" in soft money). As this Article was going to press the Third Circuit determined that FECA's ban on corporate contributions remains valid notwithstanding corporate soft money donations. See Mariani v. United States, No.993875, 2000 WL 637394 (3d Cir. May 18, 2000) (en banc).

113. See, e.g., Sorauf, supra note 109, at 32 . In fact, many of the studies of state LCCs that found that these organizations focus almost exclusively on electability, not ideology or party loyalty, involved states in which there are no limits on party contributions to state 
control over party campaign treasuries to unduly influence party officeholders does not, by itself, seem sufficiently serious to justify limits on party support for candidates.

2. Dilution or Concentration? Private Contributors, the Parties, and the Candidates. - The more compelling issue of corruption posed by party money is not undue party influence over candidates, but rather, the ability of private donors to use the parties as a means of evading the limits on donors' contributions to candidates. Party committees raise their money from private donors. With relatively tight limits on direct donations by individuals and PACs to candidates, donors could give money to the parties to circumvent those limits, or to supplement the money that is given under the limits. The party could, in effect, serve as a conduit for passing along contributions from private donors to candidates.

In California Medical Association v. FEC, the Supreme Court upheld FECA's limits on donations by a parent organization to its own PAC on just this theory. ${ }^{114}$ Given that FECA allows a parent organization to set policy for its PAC, ${ }^{115}$ there would seem to be no stronger instance of donor-recipient identity, and no weaker case for donor-recipient corruption, than this one. But the Court reasoned that although an organization's donation to its own PAC presents no danger of corruption in itself, if contributions by the organization to the PAC were unlimited the organization might, in effect, give through its PAC in order to circumvent the limits on the organization's direct contributions to candidates. ${ }^{116}$ Thus, contributions by an organization to its PAC can be limited in order to "protect the integrity of the contribution restrictions" on donations to candidates. ${ }^{117}$ Similarly, the prevention of such "conduit corruption" provides a constitutional foundation for limiting both party support for candidates and private donor support for parties.

In their Colorado Republican amicus brief, however, the political scientists in the Committee for Party Renewal denied that unlimited party spending presented a danger of conduit corruption. As they put it: "Parties are too large and too diverse to be controlled by any special interest. The old rule of sanitary engineers applies: the solution to pollution is dilution." 118 Justice Thomas, in his Colorado Republican opinion, agreed,

legislative candidates. In 1996, in 31 states, there were no limits on party contributions to candidates for the lower house of the state legislature in 31 states. See Malbin \& Gais, supra note 33 , at $17-19$.

114. 453 U.S. 182, 197 (1981).

115. See 11 C.F.R. $\S 114.5$ (d) (1999), FEC Advisory Op. 1975-23 (1975); see also Pipefitters Local Union No. 562 v. United States, 407 U.S. 385, 415-17 (1972).

116. California Med. Ass'n, 453 U.S. at 198-99.

117. Id. at 199 (plurality opinion). See also id. at 202-04 (Blackmun, J., concurring).

118. Brief Amicus Curiae for Committee for Party Renewal at 17, Colorado Republican Fed. Campaign Comm. v. FEC, 518 U.S. 604 (1996) (No. 95-489). In its decision invalidating FECA's coordinated expenditure limitations, the Tenth Circuit closely paraphrased the Committee for Party Renewal's Supreme Court brief, determining that "[p]arties are simply too large and too diverse to be corrupted by any one faction." 
stating that American political parties have "numerous members with a wide variety of interests," thus ensuring that "the influence of any one person or the importance of any single issue within a political party is significantly diffused," and that "there is little risk that an individual donor could use a party as a conduit for bribing candidates." 119 On remand, Judge Nottingham reached a similar conclusion, finding "contributor-to-party-to-candidate pressure" to be "an unlikely avenue of corruption." 120

By contrast, decisions of two state supreme courts and one federal district court have relied on the possibility of conduit corruption in upholding the constitutionality of state laws limiting party donations to candidates in state races. The Wisconsin Supreme Court looked to the legislative history of the state's campaign finance law, which discussed the danger that PACs could evade the limits on their donations to candidates by using the parties as conduits for PAC funds. ${ }^{121}$ The Alaska Supreme Court cited an affidavit from a former governor of the state who stated "that pass-throughs (donations to a party that are earmarked for a candidate) under the pre-reform system 'made a mockery of contribution limits and turned political parties into money launderers.' "122 A federal district court in Colorado upheld that state's restriction on party spending in support of candidates because of evidence that the state's Republican party had been used as a conduit for PAC contributions to candidates. ${ }^{123}$

See Colorado Republican Fed. Campaign Comm. v. FEC, No. 99-1211, 2000 WL 554688, at *10 (10th Cir. May 5, 2000).

119. Colorado Republican Fed. Campaign Comm. v. FEC, 518 U.S. 604, 647 (1996) (Thomas J., concurring).

120. FEC v. Colorado Republican Fed. Campaign Comm., 41 F. Supp. 2d 1197, 1211 (D. Colo. 1999).

Judge Nottingham defined corruption narrowly as a literal exchange of dollars for legislative votes, and rejected the idea that corruption could include more indirect influences of campaign contributions on legislative decisionmaking. See id. at 1209-11. There is evidence, however, that campaign contributions have their primary impact on legislative participation in committees. Contributions make it more likely that members will work actively to support the interests of donors, for example by proposing and supporting amendments, opposing hostile amendments, or participating in a committee mark-up. See Richard L. Hall \& Frank W. Wayman, Buying Time: Moneyed Interests and the Mobilization of Bias in Congressional Committees, 84 Am. Pol. Sci. Rev. 797, 810 (1990). Such action may be as valuable to donors as votes on the floor of Congress.

121. See Gard v. Wisconsin State Elections Bd., 456 N.W.2d 809, 814-15 (Wis. 1990).

122. State v. Alaska Civil Liberties Union, 978 P.2d 597, 626 (Ak. 1999). The Alaska Supreme Court also upheld limits imposed by the state legislature on contributions to the parties. See id. at 625 .

123. Citizens for Responsible Gov't State Political Action v. Buckley, 60 F. Supp. 2d 1066, 1080-81 (D. Colo. 1999). The court also found that limits on contributions to the parties "are an appropriate means by which to protect the integrity of the entire system of campaign contributions," but determined that the specific dollar contribution limit in the Colorado law was lower than could be justified by the purpose of preventing corruption. See id. at $1088-89$. 
Certainly, the national party committees have the capacity to launder donations. Prior to the enactment of FECA, the CCCs typically operated as money conduits, funneling large donations from particular contributors to specified candidates. ${ }^{124}$ To be sure, contemporary party committees appear to be much more active and sophisticated in soliciting funds and determining how those funds will be spent. For the most part, parties do not literally hand over money received from particular donors to specified candidates. ${ }^{125}$ Party committees can and do make their own independent strategic judgments concerning which races most require the deployment of campaign money. But the rise of soft money, the enormous disparity between FECA's limits on individual and PAC donations to candidates and the much larger sums given in soft money, and the role of federal officeholders in soliciting soft money contributions to the parties suggest that donor-to-party-to-candidate conduit corruption is a real possibility.

Small donors may have little influence over how the parties use their donations, but a substantial portion of hard money donations to the parties consists of very large gifts. In $1996,86 \%$ of the hard money in excess of $\$ 200$ given by individuals to the national Democratic party consisted of gifts of $\$ 1000$ or more; $46 \%$ came in donations of $\$ 10,000$ or more. Large gifts were a substantial, albeit slightly smaller share of donations to the national Republican party: Donations of $\$ 1000$ or more amounted to $52 \%$ of hard money individual donations of $\$ 200$ or more, while donations of $\$ 10,000$ or more amounted to $15 \%$ of hard money individual donations. ${ }^{126}$

Soft money provides donors with even greater opportunities to reach candidates through the parties. In 1997-98, there were almost 25,000 donors who gave $\$ 200$ or more to the national parties' soft money accounts. ${ }^{127}$ Their contributions came to $\$ 176$ million, or about $80 \%$ of total party soft money. Of these, just 700 donors (or $3 \%$ of those giving $\$ 200$ or more) provided $40 \%$ of the aggregate amount provided by the $\$ 200+$ donors, averaging about $\$ 97,000$ each. As previously noted, the top 390 donors each contributed $\$ 100,000$ or more-and many contributed far more than that. These amounts are well above FECA's $\$ 1000$ per election limit on individual donations to candidates and the Act's $\$ 5000$ per election limit on PAC donations to candidates. When all donations

124. See Brooks Jackson, Honest Graft: Big Money and the American Political Process 56 (1988); Kolodny, supra note 25, at 79, 86, 90, 94, 97; see also Shea, supra note 110 , at 25 .

125. Such a direct pass-along of donations is illegal under FECA, which provides that contributions by an individual or a PAC which "are in any way earmarked or otherwise directed through an intermediary or conduit" to a candidate "shall be treated as contributions from such person to such candidate.” 2 U.S.C. $\S 441$ a(a) (8) (1994).

126. See Biersack \& Haskell, supra note 51, at 160.

127. See Public Disclosure, Inc., supra note 43. FECA requires parties to itemize by name of donor and size only those donations at or above $\$ 200$. Consequently, there is far more information about these donations than about donations under $\$ 200$. 
from a particular sector or industry are aggregated, the sums in questions can be enormous. ${ }^{128}$ Surely, such large donors can be expected to have some say over how their contributions are spent, and can influence party giving and spending decisions. ${ }^{129}$

Moreover, party fund-raising practices establish close links between officeholders and potential donors to the parties. Federal officials are directly involved in soliciting contributions for the party committees' soft money accounts. ${ }^{130}$ President Clinton and Vice President Gore were prominently involved in raising money for the Democratic party's soft money operations, and Bob Dole raised Republican soft money in connection with his 1996 presidential bid. Democrats offered their $\$ 50,000+$ donors intimate dinners with the President, small-group coffees in the White House Map Room, and overnight stays in the Lincoln Bedroom. ${ }^{131}$ Republicans provided members of their Team 100-those who gave $\$ 100,000$ or more-with a three-day opportunity to golf with Senate Majority Leader Lott, Speaker Gingrich, and then-House Appropriations Committee Chair (and briefly Speaker-designate) Livingston at The Breakers at Palm Beach. ${ }^{132}$ In 1995-96, "[d]inners, weekend outings, and other events were regularly used by both major parties to give major donors a sense that they are close to power."133 The DNC raised \$27 million from the 350 people invited to attend the notorious White House coffees with President Clinton; of this amount $\$ 3.1$ million came from donors who made their contributions within a week of attending the coffee. ${ }^{134}$ In the current Congress, as the Wall Street Journal recently reported, "cash-for-access confabs on pending bills are business as usual in Washington." 135

Certainly, parties are aware of which candidates, which dinners or other events, or which fundraising appeals highlighting particular candidates, drew contributions from which donors. Funds raised for the Democratic Party by Hillary Rodham Clinton, for example, are likely to be

128. See Jeffrey Taylor, GOP to Get "Soft Money" Tobacco Aid, Wall St. J., Jan. 7, 2000, at A16 (reporting that tobacco company executives say industry will donate "at least $\$ 7$ million" toward the 2000 elections "mostly in unregulated 'soft money' contributions to Republican Party committees").

129. Cf. Joe \& Wilcox, supra note 83 , at 62 ("When individuals give $\$ 1,000$ to a presidential candidate they cannot expect much in return, but a contribution of $\$ 500,000$ or an industrywide contribution of $\$ 4$ million is perhaps a different matter.").

130. Prohibited and Excessive Contributions; "Soft Money," 63 Fed. Reg. 37,722, 37,728 (1998) (to be codified at 11 C.F.R. $\$ \$ 102,103,106$ ) (proposed July 13, 1998).

131. See Alison Mitchell, Building a Bulging War Chest: How Clinton Financed His Run, N.Y. Times, Dec. 27, 1996, at A1.

132. See Katharine Q. Seelye, G.O.P. Reward for Its Biggest Donors: 3 Days of Rubbing Elbows With Party Leaders, N.Y. Times, Feb. 20, 1997, at B9.

133. Biersack \& Haskell, supra note 51, at 173.

134. See Daniel M. Yarmish, The Constitutional Basis for a Ban on Soft Money, 67 Fordham L. Rev. 1257, 1281 n.217 (1998).

135. Phil Kuntz, Cash-for-Access Policy Forums on Bills Are Common, Controversial in Senate, Wall St. J., Jan. 25, 2000, at A16. 
spent by the party in coordination with, or issue advocacy for, her New York Senate race even if the money is not specifically earmarked for her campaign. ${ }^{136}$

Finally, fundraising for party committees does not simply provide donors with special access to specific federal candidates, but directly connects large donors with the federal government itself. Political scientists conventionally distinguish among the "party-in-electorate," the "party-asorganization," and the "party-in-government." 137 Under this division, the "party-as-organization" provides money, staff and other resources for party candidates. The "party-in-government," meanwhile, organizes the executive branch and Congress, provides legislative leadership, determines the composition and control of committees, and ultimately, shapes the legislative agenda, the policymaking process and the decisions and votes of those who hold elective office. Under the current campaign finance system, however, the "party-as-organization" and the "party-in-government" are increasingly merged. Members of Congress constitute and control the CCCs that play the leading role in providing party money and campaign services to congressional candidates. The President typically controls his party's national committee, and once a favorite has emerged for the presidential nomination of the other party, that candidate and his party's national committee typically work closely together. As a result, large donations to the party organization are effectively donations not just to specific candidates but to the party-in-government's leadership, who use that money to protect or expand their power in government, by spending in congressional races and the presidential election.

The danger, then, is not simply that party committees will channel private money to particular candidates, but that party leaders are providing large party donors with direct access to the leaders of the government-who happen to be the party leaders themselves. Party committees do not so much dilute and "cleanse" private interest money as centralize it and focus it on the President and the congressional leadership. This process can make it easier for large private interests to influence the legislative process. Instead of donors having to reach out to multiple individual members of Congress, contributions to party campaign committees place donors in direct contact with the legislators who dominate the legislative process. ${ }^{138}$ There is now the potential for large donors to "corrupt"

136. See, e.g., Susan B. Glasser, Clinton Taps Big Donors For Special N.Y. Account, Wash. Post, Jan. 4, 2000, at A1 (reporting that although donors to the Democratic Party did not receive commitments that funds raised by Hillary Rodham Clinton would be used in her New York Senate race, "at least some of the contributors clearly believe their checks effectively amount to a quid pro quo. They give money to the DSCC [Democratic Senatorial Campaign Committee], which puts it back into the New York race.” ).

137. See, e.g., Aldrich, supra note 109, at 10.

138. See, e.g., Sorauf, supra note 109, at 31 (noting that party committees offer donors "longer-run personal relationships with important, even leading policymakers. Above all, they offer access to a whole cohort of party candidates and incumbents rather than access merely to a single candidate or incumbent."). 
not just individual candidates but the parties, and, thus, to "corrupt" the government itself since the party leaders for election fundraising purposes are increasingly the same as the leaders of the parties in government.

Given the web of relations linking major donors, party committees, and elected officials, large donations to the parties and spending by the parties in support of their candidates clearly implicates Buckley's concern, recently reaffirmed by the Supreme Court in Nixon v. Shrink Missouri Government $P A C$, with "'improper influence' and 'opportunities for abuse' in addition to 'quid pro quo arrangements," " resulting from "politicians too compliant with the wishes of large contributors." 139 The evidence from the states, the very large size of soft money contributions, and the role of the President and leading members of Congress in fundraising for large donations to the parties all indicate that conduit corruption is a sufficiently great danger in practice as well as in theory to support limits on both donations to the parties and on party direct support for candidates. ${ }^{140}$

\section{Reforming the Party Money Rules}

As outlined above, the parties are eroding the basic elements of our campaign finance system. Due to the combination of party issue advocacy and independent spending, limits on party spending in support of candidates are effectively nonexistent. This development undermines the spending limits that are a central feature of publicly funded presidential elections, and that would probably be a part of any system for the public funding of congressional elections. The parties' circumvention of FECA's limits on their spending in congressional elections also enables large donors to effectively avoid FECA's contribution limits. The rise of soft money, and its growing use in paying for party issue advocacy, has substantially undermined the restrictions on the ability of wealthy donors, corporations, and unions to participate financially in federal elections. Campaign finance reform cannot survive unless the loopholes developed or exploited by the parties are plugged.

This can be done, consistent with the Buckley doctrine, provided the differences between parties and other political organizations are taken into account in interpreting Buckley. The structural and functional differences between parties and PACs should lead to a broader definition of coordination and express advocacy in cases where party spending con-

139. 120 S. Ct. 897, 905 (2000) (citing and quoting Buckley).

140. See id. at 906 ("The quantum of empirical evidence needed to satisfy heightened judicial scrutiny of legislative judgments will vary up or down with the novelty and plausibility of the justification raised. Buckley demonstrates that the dangers of large, corrupt contributions and the suspicion that large contributions are corrupt are neither novel nor implausible."). For extensive judicial fact-finding concerning the role of party committees in linking donors to candidates and elected officials as part of the quest for soft money, see Mariani v. United States, 80 F. Supp. 2d 352, 391-407 (M.D. Pa 1999). 
cerning party candidates is at stake. So, too, the nexus of large donors, party committees, and the parties-in-government adequately justifies limits on all donations to the parties, and on party support for candidates.

Reforming the party money rules, however, should not consist solely of new restrictions on the parties. Party money also plays a positive role in the campaign finance system. ${ }^{141}$ As a result, once FECA is amended to subject all party money involved in federal election campaigns to regulation, then some of the hard money limits, particularly those dealing with party spending, could be raised.

\section{A. Independent Spending}

As I suggested in Part II, Colorado Republican's protection for party independent spending reflects a view that parties are little different from PACs and ignores the ongoing structural relationships and shared electoral goals of candidates and their parties. Assuming that Colorado Republican, and particularly its conclusions that parties are capable of independent spending and that such spending is constitutionally protected from limitation, remains good law, the key goal of campaign finance reform ought to be the redefinition of "independence" in the party context.

Currently, the distinction between independent spending and spending coordinated with a candidate turns on the relationship between the candidate and the spender with respect to specific communications. Spending is deemed coordinated only where the candidate or her agents control, or engage in "substantial discussion or negotiation between the campaign and the spender over, a communication's (1) contents; (2) timing; (3) location, mode, or intended audience ... or (4) 'volume' (e.g., number of copies of printed materials or frequency of media spots)."142

Such a standard may make sense with respect to spending by PACs and individuals. PACs and political activists are structurally distinct from the candidates they back, and they have goals other than the election of candidates. Because PACs and candidates lack ongoing organizational relationships, effective coordination may require close interactions concerning particular communications. Moreover, PAC speech-even when expressly calling for the election of a candidate-may reflect an alternative or additional goal of putting a particular issue before the electorate and making that issue central to the campaign. As a result, it protects the PAC's interests in speaking independently to require collaboration concerning a particular message as a precondition to a finding of coordination. To be sure, PACs and other organizations long ago learned how to assure that their spending benefits the candidates they intend to benefit without formal cooperation, but it is still appropriate to require the defi-

141. See infra text accompanying notes 165-169.

142. FEC v. Christian Coalition, 52 F. Supp. 2d 45, 92 (D.D.C. 1999). 
nition of independent spending to take into account the independent interests of non-party organizations. ${ }^{143}$

Parties, however, are in quite a different relationship to their candidates. There are so many ongoing and longstanding ties between candidates and parties that coordination may be easily accomplished without formal contacts concerning a particular ad. As the FEC has noted,

party committees are in regular contact with their candidates, help develop candidate messages and campaign strategy, and routinely share overlapping consultants, pollsters, fundraisers, and other campaign agents .... . [T] hese consultations, discussions, and arrangements involve face-to-face meetings, telephone conversations, and exchanges of paper and electronic mail on a regular basis, sometimes daily, and take place at both the staff level and higher levels. ${ }^{144}$

More important, once a party has embraced a candidate, their electoral goals are the same-the election of that candidate. Parties do not seek to interject new issues into the campaign; they seek to help their candidates win so that the party can hold or retain power in government. Consequently, the central issue in determining whether party spending is independent or coordinated should be not whether the particular communication is independent or coordinated, but whether the party has firmly allied itself with the candidate it is supporting.

I would argue that a party has so committed itself to a candidate once it has (i) nominated or (ii) made a direct contribution to, or a coordinated expenditure with, that candidate. ${ }^{145}$ This approach accepts the constitutional point of the Colorado Republican plurality that a party organization may engage in election-related spending before it commits itself to a particular candidate, and that such spending should enjoy the protections available to independent expenditures. But this proposalwhich would be implemented by an amendment to FECA spelling out the definition of coordinated party expenditure-recognizes the real-world fact that once a party has tied itself to a candidate, the party and the

143. I do not intend to validate the current distinction between independent and coordinated expenditures in the nonparty context. I simply accept it with the goal of showing that the differences between political parties and other organizations justify a narrower definition of "independence" in the party context.

144. Independent Expenditures and Party Committee Expenditure Limitations, 62 Fed. Reg. 24,367, 24,369-70 (1997).

145. As this Article was going to press, the United States Court of Appeals for the Tenth Circuit held that FECA's limits on party coordinated expenditures are unconstitutional. See Colorado Republican Fed. Campaign Comm. v. FEC ("Colorado Respublican II"), No. 99-1211, 2000 WL 554688 (10th Cir. May 5, 2000). Needless to say, if Colorado Republican II stands, my recommendations for a narrower redefinition of party independent expenditures would be rendered irrelevant. For a brief discussion of Colorado Republican II, see infra notes 174-190 and accompanying text. 
candidate are organizationally intertwined and share the exact same electoral agenda: the election of the candidate. ${ }^{146}$

\section{B. Party Issue Advocacy}

Party issue advocacy poses an even greater threat to campaign finance laws than does party independent spending. Not only is issue advocacy exempt from spending limits, but issue ads may be paid for with soft money, thus allowing wealthy individuals, corporations, and unions to participate directly in financing campaign ads. ${ }^{147}$ Consequently, the most pressing issue for campaign finance reform is the control of party issue advocacy.

My approach to party issue advocacy is essentially the same as my approach to party independent spending. The Constitution permits the regulation of election-related speech, but not of other political speech. ${ }^{148}$ As a result, we need to draw a line between election campaign spending and other political spending. That line must be sharp and objective, and it must accurately distinguish between election-related and non-electionrelated speech. Parties as well as PACs and individuals are capable of engaging in non-election-related speech, and when they do so they should receive the full protection of the Constitution. But the determination of which communications are election-related, or express advocacy, and which are non-election-related, or issue advocacy, is necessarily affected by the identity of the speaker.

As I noted in Part II, non-party organizations and individuals have significant goals other than winning elections. For them, winning elections is likely to be a means to the end of advancing certain policy goals, rather than an end in itself. When they engage in speech that mingles references to elected officials or candidates and issues, it is quite possible that their aim is to influence official decisionmaking or even the discus-

146. The proposal is at odds with the Minnesota district court decision in Republican Party of Minnesota $v$. Pauly, which invalidated a Minnesota law that provided that party spending in support of a nominee is presumptively coordinated with the candidate. $63 \mathrm{~F}$. Supp. 2d 1008, 1012-19 (D. Minn. 1999). I believe that Pauly is mistaken and should not be followed.

The Shays-Meehan bill passed by the House of Representatives in 1998 and 1999 includes a more limited proposal, providing that once a party has nominated a candidate it can undertake either independent or coordinated spending for that candidate, but not both. See H.R. 417, 106th Cong., § 205 (1999); H.R. 3526, 105th Cong. § 204 (1998). That proposal would allow a party to engage in unlimited spending on behalf of a nominee, as well as to engage in both coordinated and independent spending for the candidate prior to formal nomination. This solution does not adequately address the potential for party independent spending to subvert the limits on party support for candidates.

147. Issue ads are also exempt from FECA's reporting and disclosure requirements. That may be less important for the national political party committees which are independently subject to reporting and disclosure requirements, but it does allow issue spending by non-party groups to avoid disclosure.

148. See Buckley v. Valeo, 424 U.S. 1, 39 (1976). 
sion of issues in the electoral context, rather than the election itself. To be sure, even speech by non-party organizations that combines discussions of issues with references to candidates is likely to be election-related when broadcast or published in the days and weeks immediately before election day. ${ }^{149}$ Still, the definition of express advocacy must acknowledge that non-party speakers have important political interests other than the election of candidates.

Parties are quite different. Winning elections, and thereby political power, is their preeminent concern. When party communications combine references to issues with references to a candidate, they are using the issues to advance the candidate and win the election; they are not using the candidate to advance the issues.

Not all party speech is necessarily election-related. Party activists, including elected officials, are interested in issues, and it is possible for party committees to spend money whose sole purpose and likely effect is to influence public thinking about issues. And party speech that is truly about issues is entitled to the same constitutional protection as the issue speech of other organizations. The question, then, in light of the distinctive focus of the major political parties on elections and the evidence presented in Part II of how parties have come to use speech currently defined as issue advocacy to advance their electoral agendas, is where to draw the elections/politics line when party spending is at stake.

I propose that all communications by the committees of the major political parties that clearly identify by name or likeness a candidate for federal office ought to be treated as express advocacy. This approach is consistent with the First Amendment goal of avoiding vague regulation: The "clearly identified candidate" test provides a bright, objective line for distinguishing one set of communications from another. If parties want to disseminate messages concerning issues, they may do so as long as those messages avoid referring to clearly identified candidates. But the test also reflects the evidence that party communications that mention candidates-even those that eschew the "magic words" of express advocacy-are really part of the party's campaign to promote the election or defeat of the candidates mentioned. In this way, the test protects true party issue advocacy, but defines such issue advocacy in terms appropriate to the distinctive institutional function of political party committees, to the predominance of electoral over issue goals in spending by the major parties, and to the evidence of the parties' exploitation of advertising that is clearly election-related, but falls outside the current definition of express advocacy.

In effect, this approach links party speech to candidate speech. I previously explained that when a candidate spends money to broadcast a campaign message, that is automatically considered to be election-related speech even when the candidate refrains from using the "magic words" of

149. See Briffault, supra note 47 , at $1782-87$. 
express advocacy. ${ }^{150}$ Parties are not quite candidates, and they may have goals other than the election of a candidate. But when a party communication clearly refers to a federal candidate, it may be safely assumed that the party is working to elect or defeat that candidate. Once it has clearly invoked the name or likeness of a candidate, the party has crossed the line from the general discussion of issues to participation in an election campaign. Like a candidate's campaign speech, a party's campaign speech ought to be hard-money funded regardless of whether the speech deploys the magic words of express advocacy. ${ }^{151}$

This recommendation goes much further than the other principal proposals for regulating issue ads, ${ }^{152}$ but its tight focus on party ads justifies its broader definition of express advocacy. Party issue ads are particularly dangerous to the campaign finance system because, as the activities of the 1996 presidential election demonstrate, these ads link up unlimited corporate, union, and individual soft money donations with fundraising by elected officials and candidates, and they directly undermine the limits on spending by publicly funded candidates. By the same token, because leading federal officials are centrally involved in the fundraising that pays for issue advocacy, and because issue advocacy has become such an integral part of candidates' campaigns, it is much easier, from an anticorruption perspective, to justify stringent regulation of party issue ads than of comparable ads of non-party organizations or individuals.

\section{Soft Money}

The constitutional case for eliminating soft money contributions is relatively straightforward. As a form of contribution, soft money can be regulated if it presents a danger of corruption or the appearance of cor-

150. See Buckley, 424 U.S. at 79.

151. Consistent with the distinction between coordinated and independent spending, party spending that refers to a candidate would still be independent, and exempt from FECA's spending limits, if the party had not nominated the candidate (or, where the speech is critical of the candidate, had not nominated her opponent) or contributed to the candidate (or her opponent).

152. The Shays-Meehan bill, which has twice passed the House of Representatives, would widen the definition of express advocacy to include communications that (i) express "unmistakable and unambiguous support for or opposition to one or more clearly identified candidates when taken as a whole and with limited reference to external events, such as proximity to an election" or (ii) refer to a clearly identified candidate and are aired on television or radio within sixty days of an election in a state in which the candidate is running. H.R. $417 \S 201$; H.R. $3526 \S 201$. The FEC, by regulation, has adopted the "unmistakable and unambiguous support" test, 11 C.F.R. $\$ 100.22$ (b) (1) (1999), but that regulation has been invalidated in the courts. See Right to Life of Dutchess County, Inc. v. FEC, 6 F. Supp. 2d 248, 254 (S.D.N.Y. 1998); Maine Right to Life Comm., Inc. v. FEC, 914 F. Supp. 8, 13 (D. Me. 1996), aff'd 98 F.3d 1 (1st Cir. 1996); see also Kansans For Life v. Gaede, 38 F. Supp. 2d 928, 936-38 (D. Kan. 1999) (enjoining Kansas Governmental Ethics Commission from enforcing a definition of express advocacy that is broader than an explicit call for a vote for or against a candidate); Briffault, supra note 47 , at $1780-87$ (reviewing proposal for regulating issue advocacy). 
ruption. Given the size of soft money donations by individuals, corporations, unions, and other organizations, and the direct involvement of federal officials in raising these funds, the corruption danger posed by soft money is manifest. ${ }^{153}$ The current, administratively created exemption for soft money is based on the theory that soft money is used for nonfederal purposes, but over the last two decades a central function of soft money has been to influence federal elections. In 1996, roughly onequarter of all national party soft money expenditures were undertaken by the four party congressional campaign committees. ${ }^{154}$ These are organizations composed of members of Congress whose sole raison d'etre is electing federal candidates. How is it possible for any of that money to be considered non-federal in any meaningful sense? The remainder of the national party soft money spending was undertaken by the Democratic and Republican National Committees which, in presidential election years, are heavily focused on winning that election. ${ }^{155}$ Soft money spending by state parties, in turn, is also usually controlled by the national committees which are the sources of state party soft money funds. ${ }^{156}$

To be sure, some soft money funds activities, such as voter registration and partisan voter mobilization drives, that benefit both federal and non-federal candidates. But even then the non-federal component also benefits federal candidates, since it frees up hard money that would otherwise have been used to fund those activities and allows the parties to spend more on direct contributions to candidates or on coordinated expenditures involving express advocacy.

Professor Bradley Smith has argued that since party issue advocacy expenditures are constitutionally protected from limitation, it would be unconstitutional to limit soft money contributions to the parties that are used to fund party issue advocacy. ${ }^{157}$ I have just argued that in the party context express advocacy may be more expansively defined so as to cover most of what is now currently considered to be issue advocacy. If so, such advocacy would have to be hard-money funded.

Even if I am mistaken, and party spending that currently falls under the rubric of issue advocacy is constitutionally immune from limitation, soft money restrictions, including restrictions on soft money that would be used to fund issue advocacy, ought nevertheless to be constitutional. Although Buckley held that expenditures by candidates present no danger of corruption, and thus may not be limited, it also found that the contributions that finance those expenditures may be regulated when they present dangers of quid pro quos that undermine the integrity of the

153. See Mariani v. United States, 80 F. Supp. 2d 352, 407-18 (M.D. Pa. 1999).

154. See Biersack \& Haskell, supra note 51, at 172.

155. See Crotty, supra note 73, at 212 (noting that in 1996 the DNC "worked interchangeably with the White House as an extension of the presidential campaign").

156. See, e.g., Mariani, 80 F. Supp. 2d at 384-85; Bibby, supra note 109, at 43-44.

157. See supra note 66 , and accompanying text. 
political process. ${ }^{158}$ So, too, even if so-called issue advocacy expenditures undertaken by the parties are immune from restriction, limits on contributions to parties to fund issue advocacy are constitutional if they are necessary to prevent corruption of the political process. Given the dangers of undue influence implicit in the process by which the soft money used to fund party issue advocacy is raised, restrictions on soft money should be constitutionally valid.

Thus, Congress should amend FECA to require that all money raised by federal officials and candidates for their own campaigns or for their parties, all money raised by national party committees, and all money raised by state parties to be used in connection with federal election activity comply with FECA's hard money dollar limits. ${ }^{159}$ This measure is necessary to restore the integrity of the campaign finance laws, and is surely constitutional. ${ }^{160}$

158. See Buckley v. Valeo, 424 U.S. 1, 23-35 (1976).

159. This is the essence of the Shays-Meehan bill, H.R. 417, 106th Cong. $§ 101$ (1999) (amending $\S 323(\mathrm{a})$, (b), (c) of FECA). Shays-Meehan would allow state parties to continue to use money that does not comply with FECA to pay for the nonfederal share of their administrative and overhead expenses, as determined by the FEC, and it would permit federal officeholders to raise nonfederal money when they are running for state office. See id. §323(b)(2)(B)(v), (e)(2). These exceptions seem both reasonable and consistent with the basic thrust of assuring that money used in federal elections complies with the restrictions of federal election law.

160. A serious and non-constitutional objection to limits on party soft money fundraising, as well as to restrictions of party issue advocacy spending, is that any such regulation is likely to drive more campaign money into the coffers of non-party organizations. This could have two consequences. First, many of these independent political committees are exempt from federal reporting and disclosure requirements, yet benefit from Section 527 of the Internal Revenue Code, which makes donations to certain political organizations exempt from gift tax, and makes contributions received by such organizations exempt from income tax. See, e.g., John M. Broder \& Raymond Bonner, The 2000 Campaign: The Money Factor; A Political Voice, Without Strings, N.Y. Times, Mar. 29, 2000, at A1 (describing issue advocacy spending of tax-exempt "Section 527" organizations); cf. Dennis Moore, 527 Organizations: A Right to Know and a Responsibility to Act, Roll Call, February 24, 2000 (member of Congress calling for application of FECA reporting and disclosure requirements to Section 527 organizations). As a result, tightening up on party activities could have the perverse effect of decreasing the amount of information available to the voters concerning the sources of campaign money, and greatly increasing the campaign role of organizations which, unlike the major political parties, are not accountable to the public.

Second, many of these independent organizations have loose affiliations with the major parties. See, e.g., Full Disclosure, Roll Call, April 6, 2000 (discussing relationship between House Majority Whip Tom Delay and a Section 527 entity called "U.S. Family Network"); Todd S. Purdum, A New Player Enters the Campaign Spending Fray, N.Y. Times, April 2, 2000, at A24 (discussing the role of "Shape the Debate," a nonprofit political organization created by the owner of a Republican consulting firm and benefiting from the fundraising of former California Republican Governor Pete Wilson); Broder \& Bonner, supra (discussing activities of Republicans for Clean Air, and noting the role of Republican members of Congress in establishing Section 527 organizations). As a result, many of the new limits on party activities might be evaded by the emergence of shadowy 


\section{Raising the Hard Money Limits}

The goal of bringing all party money under FECA is not anti-party, but, rather, pro-campaign finance regulation. It does not assume that party participation in campaign financing is a bad thing. Instead, it proceeds from the finding that party committees, because of their close connections to both donors and candidates, occupy a uniquely strategic position in the campaign finance system. Failure to limit the parties threatens the collapse of the system. But once party money is effectively regulated, there is much to be said for an expanded party campaign finance role. Indeed, with its higher limits on donations to the national parties and its provisions for party coordinated expenditures and grassroots expenditures, FECA already accords the parties a relatively privileged position.

Three factors support a prominent party role in funding campaigns. First, compared to PACs and individual donors, parties are far more likely to give to challengers. A central problem of our campaign finance system is its failure to provide challengers with adequate funding. According to a recent study of congressional elections by the Committee for Economic Development, " $[\mathrm{t}]$ he majority of House challengers now raise and spend so little that they cannot wage a viable campaign." Indeed, $60 \%$ of House

nonprofit political organizations that are nominally independent but de facto allied with one of the major parties.

Taking the latter point first, evasion of restrictions on the parties is likely to be a serious concern. Even under current law the parties are actively involved in working with nominally independent groups in order to evade FECA's limitations on party activities. See, e.g., John F. Bibby, Party Networks: National-State Integration, Allied Groups, and Issue Activists in The State of the Parties: The Changing Role of Contemporary American Parties, supra note 32, at 69, 75-81. The problem could worsen if FECA's regulation of the parties is tightened. Effective enforcement of the proposed restrictions on the parties will require both a greater commitment of FEC resources, as well as a legal determination of when non-party committee activities are coordinated with the parties that takes into account current campaign practices. Both FEC enforcement and the independent/ coordinated activities distinction are problems endemic to campaign finance law and beyond the scope of this article. But I acknowledge that unless the FEC is able to effectively police the relationship between party committees and allied nonparty organizations, and unless the courts are willing to apply a realistic definition of "coordination," then many of the proposed restrictions, like many of the current restrictions, may prove ineffective.

The diversion of funds from the parties to independent organizations may be a less serious concern. The reduction in voter information due to lack of a reporting and disclosure requirements for nonprofit political organizations can be cured by appropriate amendments to the Internal Revenue Code. See, e.g., Amy Keller, Rep. Doggett Taking Aim at "527" Groups: Members Trying to Rein in "Super Weapon of Choice" in This Election Cycle, Roll Call, April 10, 2000 (describing congressman's plan to eliminate "stealth PACs" by requiring full disclosure of contributions and expenditures of Section 527 organizations). Moreover, when the fundraising role of elected officials and party committees composed of elected officials is curtailed, whatever harm that might result from non-party groups that are not accountable to the public playing a bigger role in campaigns will be offset by the reduction of the dangers that large soft money donors will gain undue influence over, and opportunities for special access to, government officials. 
incumbents "either had no significant opposition or outspent their opponents by a margin of 10-to-1 or more." 161 In 1998, the average House incumbent outspent the average House challenger by 2.4 to $1 .{ }^{162}$

PACs and large individual donors contribute to this fiscal edge of incumbency. Most PACs and large individual donors make contributions in order to obtain or secure access to elected officials "who are in a position to influence regulations, appropriations, or treaties that effect [sic] the environment in which the PAC's industry or workforce operates. These groups consider campaign contributions an important tool for reaffirming or strengthening their relationships with influential lawmakers."163 PACs and individuals that follow access strategies overwhelmingly favor incumbents with their contributions. ${ }^{164}$

Parties, by contrast, are more likely to support promising challengers. ${ }^{165}$ Party committees deliberately allocate their money strategically to maximize their chances of winning control of Congress. This strategy will frequently dictate sending money to a promising challenger rather than reinforcing the overloaded warchest of an incumbent facing only weak opposition. ${ }^{166}$ Thus, far more than PAC money or donations by wealthy individuals, party money promotes the value of electoral competition.

A second benefit of parties is that they devote a considerable portion of their spending to grass-roots activity, such as voter registration and voter mobilization. ${ }^{167}$ Party spending, thus, can promote citizen participation and voter turnout. The party label is an important cue for voters, providing general information about candidate orientations over a range of policy issues. An enhanced party campaign presence could improve voter understanding of the candidates and the quality of voter decisions.

Finally, as the scholars and justices who contend that parties dilute special interest money have pointed out, ${ }^{168}$ the relatively broad-based nature of parties has the potential to mitigate the politically balkanizing ef-

161. Research and Policy Comm., Committee for Economic Development, Investing in the People's Business: A Business Proposal for Campaign Finance Reform 17 (1999).

162. See id. See also Herrnson, Financing the 1996 Congressional Elections, supra note 53, at 118 (in 1996, average House incumbent outspent average House challenger by 2.7 to 1 ). The imbalance in Senate races was less dramatic, with incumbents outspending challengers by about 1.5 to 1 . See id. at 120; Committee for Economic Development, supra note 161 , at 18 .

163. Herrnson, Financing the 1996 Congressional Elections, supra note 53, at 105.

164. See id. at 109-14 (stating that in 1996, $88 \%$ of contributions of corporate PACs in House elections went to incumbents; $62 \%$ of large individual hard money donations went to incumbents).

165. See id. at 102-04; Malbin \& Gais, supra note 33, at 145-52.

166. Party committees will also give heavily to incumbents facing serious opposition.

167. See Smith, supra note 66, at 199-200; see also Stephen Ansolabehere \& James M. Snyder, Jr., Soft Money, Hard Money, Strong Parties, 100 Colum. L. Rev. 598, 617 (2000) (contending that party spending increases turnout).

168. See text accompanying supra notes $118-120$. 
fects of advocacy by special interest groups. ${ }^{169}$ Parties are less effective at muting the voices of their special interest constituents when a handful of very large donors play a preeminent role in financing party activities. However, there is much to be said for the dilution argument if the size of donations to the parties is capped.

In light of the role of the parties in promoting the democratic values of electoral competition, political participation, and public-regarding government decisionmaking, a comprehensive campaign finance reform package should combine the elimination of soft money and unlimited party spending with some increase in the permitted levels of party hard money support for party candidates. By reforming the law so as to make effective FECA's prohibitions on corporate, union, and large individual contributions, Congress would ameliorate the conduit corruption dangers posed by party support for candidates. It could then raise party spending levels so as to increase the opportunities for parties to support challengers, promote political participation, and reduce the dependence of candidates on funds provided by narrowly-focused special interest groups. This combination of reforms would make soft money and spending restrictions more politically palatable while resulting in a better campaign finance system than could be achieved via soft money and spending controls alone.

At present, parties provide only a modest portion-around $10 \%$ - of the hard money funds spent by congressional candidates, a figure which is far less than the shares provided by wealthy individuals or PACs. ${ }^{170}$ The case for increasing FECA's limits on party spending is reinforced by the rapidly increasing costs of congressional elections. FECA's limits on party direct contributions to candidates were set in 1974, and have not been adjusted for inflation. The limits on coordinated contributions have been adjusted for inflation, but from 1976 to 1996 congressional campaign costs increased at more than triple the inflation rate. ${ }^{171}$ Indeed, it is reasonable to conclude that one of the reasons for the rise of soft money is that in the absence of public funding, it has become increasingly difficult for congressional candidates to both raise the money they now need and also comply with FECA's unindexed hard money contribution limits and inadequately indexed hard money coordinated spending limits. ${ }^{172}$

169. See, e.g., Darrell M. West \& Burdett A. Loomis, The Sound of Money: How Political Interests Get What They Want 211 (1998).

170. See Herrnson, Financing the 1996 Congressional Elections, supra note 53, at 119-20.

171. See Sorauf, supra note 109 , at 52 .

172. The importance of soft money in presidential elections is also directly traceable to the inadequate levels of presidential public funding. The initial public funding allotment was set too low, and the subsequent adjustments have been inadequate to keep pace with rising campaign costs. See Richard Briffault, Public Funding and Democratic Elections, 148 U. Pa. L. Rev. 563, 586 (1999). 
Consequently, it would be a sensible campaign finance policy to accommodate the rise in the cost of campaigning over the past quartercentury by increasing the limits on party hard-money support for candidates to triple their current state and by then indexing them henceforth. The coordinated expenditure limits, which have been rising with inflation, could be doubled to take into account the difference between the inflation rate and the more rapid increase in campaign costs. ${ }^{173}$

\section{Conclusion: Campaign Finance Reform and Party Reform}

As this Article was going to press, a divided panel of the United States Court of Appeals for the Tenth Circuit, in the Colorado Republican remand case ("Colorado Republican II"), held FECA's dollar limitations on party coordinated expenditures unconstitutional. ${ }^{174}$ Colorado Republican II would enable the political parties to spend unlimited amounts of money in coordination with their congressional candidates. If it stands, the Tenth Circuit panel's decision will transform one of the specific issues discussed in this article. Striking the limits on coordinated expenditures will make independent expenditures of very limited significance, since there would be no incentive to make independent expenditures once there is no limit on coordinated expenditures. So, too, my proposal for limiting the definition of independence and expanding the definition of coordination the party context would be rendered irrelevant if coordinated expenditures cannot be limited. ${ }^{175}$

The Tenth Circuit panel decision is consistent with the arguments embraced by several Justices of the Supreme Court in Colorado Republican $I^{76}$ that party spending is not corrupting, but Colorado Republican II has its own particular wrinkles which undermine the persuasive value of its holding. First, a central theme of Colorado Republican II is that a party is "like an advocacy group." The parties "exist for noneconomic reasons . . . 'to disseminate political ideas, not to amass capital."'177 As a result, the Tenth Circuit determined that the evidentiary burden of demonstrating contributions-and a coordinated expenditure is a form of contribu-

173. Even if soft money is eliminated, limits on party spending outside the public funding context would remain appropriate. FECA's hard money limits allow PACs and individuals to make far larger contributions to party committees than to candidates, so that unlimited party spending would still allow party donors to evade the limits on donations to candidates.

174. FEC v. Colorado Republican Fed. Campaign Comm., No. 99-1211, 2000 WL 55468 (10th Cir. May 5, 2000).

175. The role of party issue advocacy might also be reduced since one value of issue advocacy is to enable the parties to avoid the limits on coordinated spending. But the importance of issue advocacy in enabling the parties to spend soft money in direct support of candidates would remain and, thus, the need to deal with party issue advocacy would remain as well.

176. Colorado Republican Fed. Campaign Comm. v. FEC, 510 U.S. 604 (1996)

177. Colorado Republican II, 2000 WL 55468, at *6 (quoting FEC v. Massachusetts Citizens for Life, Inc., 479 U.S, 238, 259 (1986)). 
tion-corrupt is much higher for a restriction on party money than for a limit on individual or PAC donations. Leaving aside the fact that parties are not simply advocacy groups but are also organizations of government officials who secure and wields public power, ${ }^{178}$ the Tenth Circuit erred in assuming that the Supreme Court's standard for determining whether a contribution corrupts turns on whether the donor gives for ideological or economic reasons. ${ }^{179}$

Colorado Republican II conflated the Supreme Court's determination in FEC $v$ Massachusetts Citizens for Life, Inc. ("MCFL"), ${ }^{180}$ that FECA's absolute ban on corporate campaign spending cannot constitutionally be applied to ideological corporations with the idea that contributions given by ideological organizations enjoy greater constitutional protection than contributions given for economic purposes. ${ }^{181}$ But the Supreme Court has never drawn such a distinction. FECA's dollar limits on individual and PAC contributions apply equally to donations by advocacy organizations or ideologically-minded individuals as to organizations and individuals with economic agendas for giving. The Supreme Court has never suggested that ideological contributions are constitutionally immune from dollar limitation. There is thus no basis in the Supreme Court's campaign finance jurisprudence for Colorado Republican II's determination that restrictions on party contributions are subject to more stringent scrutiny because parties are ideological organizations - even if it is assumed that parties are primarily ideological organizations. ${ }^{182}$

Second, the Tenth Circuit dismissed outright the argument that party spending may be limited to protect FECA's limits on individual or PAC contributions to candidates: "We will not validate limits on the protected speech of a political party as a back-door means of stemming cor-

178. See supra text accompanying note 137 for a discussion of how contemporary party campaign finance practices are eroding the traditional distinction drawn by political scientists between the party-as-organization and the party-in-government.

179. See Colorado Republican II, 2000 WL 55468, at *6 ("The opportunity for corruption or its appearance is greatest when the political spending is motivated by economic gain.”).

180. 479 U.S. 238 (1986).

181. See Colorado Republican II, 2000 WL 55468, at *6 (citing and quoting FEC v. Massachusetts Citizens for Life, Inc., 479 U.S, 238, 259 (1986)).

182. Even if $M C F L$ 's invalidation of a complete ban on campaign expenditures by an ideological corporation also applied to dollar limitations on contributions by ideological organizations to candidates, political parties are not ideological organizations within $M C F L$ 's definition. One of the "three features" $M C F L$ relied on in distinguishing corporations constitutionally entitled to an exemption from a ban on corporation expenditures from those that may constitutionally be subject to such a restriction is that exempt organizations have a "policy not to accept contributions from" business corporations and labor unions. "This prevents such corporations from serving as conduits for the type of direct spending that creates a threat to the political marketplace." $M C F L$, 479 U.S. at 263-64. But as this Article has noted, the major political parties do accept contributions-indeed, hundreds of millions of dollars worth-from business corporations and labor unions. 
porate involvement in the legislative process." ${ }^{183} \mathrm{But}$, as I have pointed out, ${ }^{184}$ the Supreme Court has held that the prevention of conduit corruption provides a constitutional justification for limiting campaign contributions. ${ }^{185}$ The Tenth Circuit concluded that any danger of conduit contributions from a donor through a candidate to a party is fully addressed by FECA's provision treating contributions given through an intermediary that are specifically earmarked for a candidate as contributions to that candidate, so that further limits are superfluous and unconstitutional. ${ }^{186}$ But the Supreme Court has held that in appropriate circumstances contributions can be curtailed in order to limit the ability of donors "who might otherwise contribute massive amounts of money to a particular candidate through the use of unearmarked contributions to political committees likely to contribute to that candidate, or huge contributions to the candidate's political party." 187 The Supreme Court has indicated that where an organization is free to engage in independent political advocacy, as parties may, then "Congress was not required to select the least restrictive means of protecting the integrity of its legislative scheme." Instead, Congress could determine that additional contribution limits "are a useful supplement" to the rule treating clearly earmarked contributions as direct contributions to the candidate. ${ }^{188}$ Moreover, there was evidence in the Colorado Republican II record that the parties do link contributions from particular donors to particular candidates without formal earmarking. ${ }^{189}$

Finally, the Tenth Circuit panel gave great weight to the vital role political parties play in our political system. ${ }^{190}$ But, as the Supreme Court recognized in Buckley, campaign contributions, which in the absence of public funding are essential for the effective operation of our electoral system, also present dangers of corruption. Where large private contributions are channeled through the parties to candidates and officeholders, the considerations that generally justify restrictions on large contributions apply to the parties as well. Moreover, limits on party money will not necessarily cripple the ability of the parties to perform their vital role. The parties flourished financially in the 1970s and 1980s when they were

183. See Colorado Republican II, 2000 WL 55468, at *8.

184. See supra text accompanying notes 114-117.

185. California Med. Ass'n v. FEC, 453 U.S. 182, 199 (plurality opinion), 202-04 (Blackmun, J., concurring) (1981); Buckley v. Valeo, 424 U.S. 1, 38 (1976).

186. See Colorado Republican II, 2000 WL 55468, at *10 (citing and quoting 2 U.S.C. $\S 441 \mathrm{a}(\mathrm{a})(8)$ (1994) and 11 C.F.R. § 110.6(b) (1) (1999).

187. Buckley, 424 U.S. at 38 (emphasis added).

188. California Med. Ass'n, 453 U.S. at 199-200 n.20.

189. See Colorado Republican II, 2000 WL 55468, at *21 (Seymour, C.J., dissenting) (citing affidavits and depositions in trial record "that although earmarking ... is illegal, prohibition is circumvented through 'understandings' regarding what donors give what amounts to the party, which candidates are to receive what funds from the party, and what interests particular donors are seeking to promote"). See also supra note 136.

190. See id. at *6-*7. 
subject to coordinated expenditure limits, and when independent expenditures, soft money, and party issue advocacy were minor or nonexistent factors in campaign finance.

Limits on party coordinated expenditures, like limits on party campaign finance practices generally, are not anti-party. It is essential for the integrity of the campaign finance laws to bring the parties back under FECA. To do so should not be seen as anti-party. Indeed, some restrictions on party campaign finance activity may actually serve the best interest of the parties. The current system, dominated by soft money and soft money-financed issue advocacy, empowers large donors and centralizes party finances and power within the parties in Washington. When party leaders can raise huge sums at White House coffees or Speakers' Club retreats, they necessarily become more sensitive to the interests of their big donors, and less attentive to their less well-heeled, rank-and-file supporters. When state party organizations rely on soft money transfers from the national parties, they, too, may become less attentive to their grassroots members and less focused on activities that build the party from the bottom up. The soft money system subtly transforms the parties from community-based clubs to Capitol Hill organizations. Controlling large donations to the parties could make the parties more participatory, and more accountable to their local activists and voters.

The goal of campaign finance reform is not to limit the parties, but to liberate the parties from corrupting influences. Once it is established that party campaign finance practices are fully subject to FECA's limits and requirements, and the danger of large donors using the parties to subvert the campaign finance laws is ameliorated, the current limits on the parties could be relaxed so as to bolster the positive role that parties play in the political process. Regulation of party campaign finance activity is, thus, not an infringement on party rights or an interference with party interests, but a means of making the parties more faithful to their capacity to promote electoral competition, grass-roots political activity, and broad-based approaches to the problems of governance. 